\title{
A Feeling for What's Best: Landscape aesthetics and notions of appropriate residential architecture in Dartmoor National Park, England
}

\begin{abstract}
In England's national parks, the design of new dwellings represents a significant and contested part of landscape planning, inseparable from park conservation ideologies and policies. Within public discourse, new housing proposals can be praised for enhancing the landscape or decried for destroying it, while the decisions of planning authorities legitimise or marginalise different points-of-view. Set in Dartmoor National Park, this paper explores the competing aesthetic interpretations of landscape and the rural as represented within the design and planning of two separate residential sites that were redeveloped between 1998-2008. Discourse analysis of interviews (with architects, planners and clients), policies, and written accounts (planning applications and associated correspondence) investigates the positions of various stakeholders in response to these housing projects and to their protected rural landscape settings. Results reveal how notions of landscape context and aesthetics vary across different stakeholder groups, with design quality, sympathetic scale and landscape enhancement proving to be key areas of contention. Differing interpretations of national park planning policy, the problematic nature of communicating and judging qualitative aspects of 'contemporary' architecture, and the ongoing emphasis on visual aspects of landscape aesthetics mean that incorporating new housing design within national park landscapes remains challenging.
\end{abstract}

Keywords: national parks, planning, housing, architecture, landscape aesthetics

\section{Introduction}

As arguably the most valued of the nation's rural landscapes, England's 10 national parks, covering $9.3 \%$ of the country, have the 'highest status of protection in relation to landscape and scenic beauty'. ${ }^{1}$ At the same time, as home to around 334,000 people, the design of housing within English national park boundaries represents a significant and contested part of rural landscape planning, inseparable from landscape conservation ideologies and policies. Reviews of English national parks in the 1980's by MacEwen and MacEwen (1987), (1982) and Blunden and Curry (1989) reveal a 'complex history that has involved many

\footnotetext{
${ }^{1}$ National Planning Policy Framework, paragraph 115 (2012).
} 
compromises' and inherent tensions (Thompson et al. 2014, 6). When new housing is proposed within such a context, notions of landscape, the rural, and "contemporary" architecture are part of public discourse and decision-making. These notions are important 'as they can legitimise (or marginalise) particular developments, aesthetics and actions in rural settlements, emphasising the power relations of different stakeholders in the rural policy field' (Donovan and Gkartzios 2014, 335). The existing literature on constructions of rurality suggests that residential development in rural spaces is highly contested (Donovan and Gkartzios 2014). In this paper, we extend this literature by investigating competing aesthetic interpretations of landscape and the rural, and their relationship to perceptions of contemporary architectural design, as evidenced within the specific context of English national parks.

The dominant landscape values associated with national park designation and protection are preserving scenic landscapes and facilitating public access to those landscapes for recreation. These values are reflected in the two English national park statutory purposes, namely 'to conserve and enhance the natural beauty, wildlife and cultural heritage of the area' and 'to promote opportunities for the understanding and enjoyment of the parks' special qualities by the public'. ${ }^{2}$ In practice, however, these values are often in conflict, while management strategies encompassing both preservation and enhancement are likewise not always reconcilable (Carr 1998).

Park planning is 'largely concerned with negotiating multiple landscape values though placemaking and conflict management' (Butler 2016, 239). In defining policy and exercising planning functions, park planners must negotiate among statutory purposes, landscape values and stakeholder aspirations. Park planning is itself a source of tension, imposing a form of cultural authority which allows freeholders to operate, but with development conditions

\footnotetext{
${ }^{2}$ Environment Act 1995, Part III National Parks, s 61.
} 
according to notions of what is "appropriate". Tensions arise when efforts by "outsiders" to categorise landscape as a conceptual system of laws and relationships conflict with the 'landscape of custom' as understood by “insiders" (Olwig 2002). To date, however, there has been a lack of literature which looks at how planning professionals handle landscape values when negotiating landscape change (Butler 2016, 239). There has similarly been 'very little research on how the rural is constructed in architectural practice as well as how these representations compare with equivalent planning and housing policy discourses' (Donovan and Gkartzios 2014, 334). In addition, in the last few decades, research on English park planning has itself been 'relatively neglected' (Thompson et al. 2014, 6).

Figure 1. "Hanging Stone Hill", Dartmoor, by Paul Moody Photography, reproduced courtesy of Paul Moody.

This paper investigates these topics through the planning process (1998-2008) of two single residential sites in Dartmoor National Park. Dartmoor, which was given national park status in 1951, covers 953 sq. $\mathrm{km}$ and is the largest open space in southern England. It is also home to around 34,000 people living in towns and villages within its boundaries. An 'exemplar of the contested countryside type' (Lowe et al. 2003, 95), Dartmoor has in recent decades been under specific and increasing pressure as a desirable place to live, with substantial in-migration, housing shortages, and rising house prices (Richards and Satsangi 2004). Indeed, this landscape exemplifies Murdoch and Lowe's 'preservationist paradox', where the very act of protecting rural areas makes them more attractive to urban migrants (Murdoch and Lowe 2003, 323). Other issues impacting on Dartmoor's residential development include an ageing population, growing numbers of people working from home, and a high proportion of energy-inefficient buildings. ${ }^{3}$

While landscape protection status in many countries excludes housing altogether, the ongoing presence of residential communities within Dartmoor reflects England's national

\footnotetext{
${ }^{3}$ Dartmoor National Park Authority, "Your Dartmoor - Issues and Challenges", http://www.yourdartmoor.org/developing/evidence/issues (accessed May 7, 2017).
} 
park history. The English national park system was established under the National Parks and Access to the Countryside Act 1949. Although based on the original American model, in England the national park idea was applied to rural landscapes where there was 'a more evident palimpsest of time-depth and cultural settlements' (Selman 2010, 384). In such landscapes, 'man made heritage and other cultural qualities', form 'essential elements of their special characteristics' (Selman and Swanwick 2010, 13). As such, English national parks are classified by the IUCN as protected area management 'Category V: Protected Landscape/Seascape', and not 'Category II: National Parks' (Dudley 2008). Also different from America, where a near-spiritual "wilderness concept" underlay its national park designations (Leonard 2007, 25), was the notion in England of landscape as "scenery", reflecting a 'somewhat escapist emphasis on aesthetics, picturesque views and a Romantic construction of nature' (Selman and Swanwick 2010, 8).

The 1949 Act reflected the need to reconcile conservation aims with the interests and views of national park stakeholders, but in practice conservation imperatives of "keeping up appearances" (i.e. maintaining the scenery) often fell short of the requirement to sustain the changing demands of the "living landscape" (MacEwen and MacEwen 1987). In 1995, in response to criticisms that national park authorities were 'slavishly adhering' to their 'conservation remit', ${ }^{4}$ a secondary duty 'to foster the economic and social well-being of local communities' was added under the Environment Act. Significantly, however, this duty was not given the status of the two park purposes, while previously, a National Parks Policy Review Committee (1974) had confirmed the primacy of the first park purpose, to conserve and enhance the landscape, over other concerns in the event of conflict. Referred to as the "Sandford Principle", this policy position was later affirmed in a National Parks Circular

\footnotetext{
${ }^{4}$ S Belli [DNPA Director of Planning], second personal interview with authors, February 13, 2017.
} 
(2010), which set out 'a joint 2030 vision for the English National Parks' (Dartmoor National Park Authority, 2008, 8).

In landscape planning, 'character is emerging clearly as the basis for describing the special qualities of individual landscapes' (Selman and Swanwick 2010, 14). In England, park planning policy requires new development to respect the "special qualities and characteristics of the parks", and the UK National Parks website sets out the "top 10" special qualities for each: Dartmoor's include its unglaciated upland landscape, archaeological features, distinctive geology and industrial history. It has been observed, however, that although the 'concept that the parks have a set of attributes that make them special is even reflected in the legislative framework', these same characteristics which must be respected are 'often ill-defined' (Thompson et al. 2014, 762).

In recent years, more formal assessments of landscape character in the shape of Landscape Character Assessments (LCA) have been employed to inform landscape plans and strategies (Tudor and Natural England 2014). LCA guidelines stress that such assessments are 'not just about visual perception', and emphasise the 'relationship between people and place' (Swanwick and Land Use Consultants 2002, 2-3). Meanwhile, wider landscape theories and policies, most notably the European Landscape Convention 2000, have challenged the 'traditional ways of perceiving landscape as a form of scenery' (Belcher and Wellman). Such methods also challenge the authority of the 'committee of experts' which reinforces the visual approach (Olwig 2007, 582, 590). In a recent study of LCAs, however, it was found that there is still a 'significant dominance of the scenic and aesthetic in the landscape description', and indeed Dartmoor's LCA of 2010 demonstrates a particular 'reliance on the visual' to explain even non-visual values (Butler 2016, 247).

Just as notions of landscape itself are changing, there is 'a growing acknowledgement of the difficulty of applying universal rules of aesthetic appeal in a meaningful way’ (Selman 
and Swanwick 2010, 14). Indeed, what makes landscapes "beautiful" is "often intimately linked to other intrinsic landscape values such as biodiversity', and 'these other values can shift perceptions of how we perceive and appreciate the beauty of landscapes' (Jorgensen 2011, 353). These shifts can happen on different temporal scales, from 'relatively rapid changes in aesthetic preferences associated with environmental awareness and education', to 'radical, long-term historical and cultural shifts in aesthetic appreciation for particular types of landscape' (Jorgensen 2011, 353). In Dartmoor, landscape perceptions have shifted strikingly from a 'barren waste', condemned in the $19^{\text {th }}$ century by those who sought to "improve" its moorland, to 'one of the most valued rural landscapes in Britain' (Kelly 2015, 10). Dartmoor's 'modern history has been troubled by the discursive tensions between Dartmoor the wilderness and Dartmoor the anthropic landscape of shifting meaning and value' (Kelly 2015, 14). In the popular imagination, however, 'there remains a close association between wilderness and the concept of national parks' (Dinnie, Blackstock, and Dilley 2012, 452).

Specifically, it was the preservation of so-called 'natural beauty' that was the key driver in English national park designation, and which continues to be enshrined in their statutory purposes (Selman and Swanwick 2010). "Natural beauty", however, has been shown to be 'a dynamic and malleable concept, potentially posing problems for consistency of interpretation', and one which must inevitably be 'related to a prevailing consensus on what people consider to be aesthetic and important to human well-being' (Selman and Swanwick 2010, 7). Even so, "natural beauty" has been shown to retain "a continuing relevance' in park landscape policy (Selman and Swanwick 2010, 4). Indeed England continues to rely heavily on "natural beauty" legislation as a basis for complying with the European Landscape Convention' (Selman and Swanwick 2010, 4). 
A key consideration for this paper is thus the perceived effect of new dwellings in "natural" and "beautiful" landscape contexts, specifically whether and how new buildings could "conserve" or "enhance" such landscapes. An early American illustration of the conflicts that can emerge over such "manipulation of scenery" was the controversial Hetch Hetchy dam development (1908-1913) in Yosemite National Park, where its supporters argued that it could be designed to enhance the natural landscape, while its opponents argued the fallacy of this concept (Leonard 2007, 25). Frederic Law Olmstead Jr., the influential American landscape architect, believed that development need not be a 'necessary evil', and that 'it is the cultural value invested in natural places through their physical development as parks that best assures the preservation of those places' (Carr 1998, 9). In England, however, a more recent study of new commercial development in national parks (Lloyd, McCarthy, and Illsley 2004, 293) found that planners, although accepting the need for a strong rural economy, were 'often unwilling to conceptualise development as capable of enhancing natural beauty' (Thompson, Garrod, and Raley 2013, 762).

It is argued here that aesthetic landscape constructs influence notions of "appropriate" architecture: appropriate in the sense of being judged 'suitable or right for a particular situation'. In landscape aesthetics generally there is 'a tendency to consider issues of fittingness, congruity and harmony' (Porteous 1996, 176). In England, national park planning authorities frequently use the term "appropriate", and related terms such as "sympathetic", in relating design objectives to conservation agendas. Dartmoor's "Design Guide” for example states that 'sympathetic and well informed design is vital', that design issues include 'appropriate quality, choice of materials, accessibility and layout', and that these various objectives should be achieved 'in a manner that is appropriate in a protected landscape' (Dartmoor National Park Authority 2011, 10).

\footnotetext{
${ }^{5}$ Cambridge Dictionaries Online, http://dictionary.cambridge.org/dictionary/english/appropriate (accessed February 15, 2016).
} 
The widespread use of such terminology supports the assertion that, in English national parks, the landscape objective in managing change is not so much "preservation" of nature but 'one of conservation where man-made change does not necessarily pose any threat to value if it is accomplished in the appropriate way' (Leonard 2007, 26). Acceptable change, in short, is that which is considered 'integral to and in keeping with, the character of the landscape’ (Selman and Swanwick 2010, 13). In the New Forest National Park, for example, a Landscape Assessor felt 'that the primary consideration of natural beauty was the presence of outstanding landscape quality [...] with an absence of atypical or incongruous features' (Selman and Swanwick 2010, 16). Similarly, in the Broads National Park, its Authority judges the town of Potter Heigham, which has 'buildings with no Broads character' [...] 'the wrong kind of landscape for their vision of a "Last Enchanted Land" (Matless 1998, 10).

It has been argued that "preserving a particular landscape aesthetic has been so successful that England's national parks 'are being preserved "in aspic" rather than evolving to reflect changing human / nature interactions' (Thompson et al. 2014, 762). A 2001 study of how architecture is addressed in English national parks found that park authorities sought to protect local character by adopting conservative approaches in planning and development control which favoured "vernacular" design, and precluded the introduction of modern architecture (Land Use Consultants 2001). It also found that public design consultations 'often meant hearing the views of a vocal group with a strong pro-conservation agenda' (Thompson, Garrod, and Raley 2013, 762). Architects add their own discourses of rurality to this debate, including the extent to which they might 'feel bound by vernacular precedent in terms of their own designs' (Upton 1983, 263).

Critics of national park planning in England point 'to the lack of innovation in design and the resistance to new development on conservation related grounds' (Thompson, Garrod, and Raley 2013, 762). Certainly, Dartmoor's New Development Design Guidance (2008) 
states that the "successful integration of a new development takes into account the traditional form, design, setting and materials of buildings in the Dartmoor National Park' ${ }^{6}$ This narrow definition harbours the danger that "regional architecture" will become a dogma, and that for buildings in National Parks, the criteria for acceptability will be any reference to local building forms, materials and construction details' (Land Use Consultants 2001, 9). In America, during the post-war "Mission 66" national park development programme, similar debates 'over national parks design' raged between those advocating traditional "rustic" design, which it was argued, would "blend in" with the scenery, and "more contemporary architecture' (Carr 2007, 132). In America, however, eventually an approach was found that "would completely redefine what it meant to "harmonize" with the unique settings of the national parks' (Carr 2007, 132).

In contrast, advocates of the English park planning system assert that it 'can also be argued to be effective with regard to cultural heritage if this is interpreted to mean the built heritage' (Thompson, Garrod, and Raley 2013, 762). Certainly the original supporters of the English national parks system 'fought hard for their governing authorities to have park planning powers believing them to be vital to conservation' (Thompson, Garrod, and Raley $2013,761)$. The very process of planning, however, can be argued to be 'rooted in restrictions, rather than in opportunity, and creativity' for architecture (Land Use Consultants $2001,7)$.

So how does creativity and new architectural design figure in Dartmoor planning? In both policy and practice, Dartmoor planners use the term "contemporary", somewhat ambiguously, to mean to a 'use of materials and details' in ways distinct from those 'based on direct historic references' (Dartmoor National Park Authority 2011, 36). Dartmoor planners make a clear distinction between the 'traditional', or 'safe route' as the Director of Planning

\footnotetext{
${ }^{6}$ Dartmoor National Park Authority, "New Development Design Guidance", (Bovey Tracey, Devon: Dartmoor National Park Authority, 2008).
} 
calls it, and 'contemporary', which, he notes, 'is still a brave step for planners to take'. ${ }^{7}$ This binary categorisation effectively ignores the wide spectrum of possible design approaches, such as neo-vernacular, critical regionalism, post-modernism and so forth. As of 2008, DNPA's guidance on new architecture was limited to the general statement that 'the DNPA encourages good contemporary design', 8 without articulating what that may entail. It did, however, make a distinction between "rural" buildings 'with an overall horizontal emphasis' and the 'taller, with a vertical emphasis' buildings in the 'towns and some larger villages'. 9 The Director of Planning makes a similar distinction between 'landscape character' sites in the countryside, and sites with a 'townscape' or 'village-scape' character. ${ }^{10}$

A more recent Design Guide (2011) is more expansive on 'Contemporary design', devoting a short section to the subject explaining that its role "should be to bring together the distinctiveness of Dartmoor' with 'sustainability issues' (Dartmoor National Park Authority 2011, 36). It suggests 'the use of planted roofs in certain contexts' and that 'a topographical feature' might be used to 'inspire an altogether more contemporary organic built form rather than a traditional rectilinear building' (Dartmoor National Park Authority 2011, 36). At the same time, however, the need to 'reduce the visual impact of a new building' is clearly stressed, with the caveat that it should not be 'strident or intrusive' (Dartmoor National Park Authority 2011, 36). It is also noted that it 'would not be appropriate to adopt this approach on a widespread basis' (Dartmoor National Park Authority 2011, 36).

\section{Research Design}

The context for this paper is a wider study of residential architecture in Dartmoor National Park since 1997. Although the national park was designated in 1951, it was not until 1997,

\footnotetext{
${ }^{7} \mathrm{~S}$ Belli, second interview.

${ }^{8}$ Dartmoor National Park Authority, "New Development Design Guidance".

${ }^{9}$ Ibid.

${ }^{10} \mathrm{~S}$ Belli, second interview.
} 
following the Environment Act 1995, that a free-standing Authority responsible for the administration and management of the national park was established, having previously been administered by a Committee on the Devon County Council. As such, this date represents a 'milestone' in the history of Dartmoor park planning. ${ }^{11}$

In this paper, two residential Dartmoor sites and their recent development histories are presented as comparative case studies. Focusing on changes between 1998 and 2008, we examine the different interpretations of landscape and the rural which emerged during the contested design and planning process of four individual houses by four different architects two on each site: one unexecuted; one built.

\begin{tabular}{|c|c|c|c|c|}
\hline & $\begin{array}{l}\text { PHASE } 1 \\
\text { Original Development } \\
\text { (pre- National Park) }\end{array}$ & $\begin{array}{l}\text { PHASE } 2 \\
\text { First Design } \\
\text { (unbuilt) }\end{array}$ & $\begin{array}{l}\text { PHASE } 3 \\
\text { Second Design } \\
\text { (built) }\end{array}$ & $\begin{array}{l}\text { PHASE } 4 \\
\text { Second Design } \\
\text { (completion and post- } \\
\text { completion) }\end{array}$ \\
\hline $\begin{array}{l}\text { Site } \mathbf{A} \\
\text { Private client }\end{array}$ & $\begin{array}{l}1930 \text { 's: bungalow } \\
\text { constructed }\end{array}$ & $\begin{array}{l}\text { The Voysey-Lutyens } \\
\text { 1993: site purchased by } \\
\text { current owners } \\
\text { 1998: planning refused }\end{array}$ & $\begin{array}{l}\text { The Underground } \\
\text { House } \\
\text { 2001: planning granted } \\
\text { conditionally }\end{array}$ & $\begin{array}{l}\text { 2007: construction } \\
\text { completed }\end{array}$ \\
\hline $\begin{array}{l}\text { Site B } \\
\text { J Powell-Tuck } \\
\text { (Architect) }\end{array}$ & $\begin{array}{l}\text { 1950's: bungalow } \\
\text { constructed }\end{array}$ & $\begin{array}{l}\text { The One-Eyed Slug } \\
\text { 2004 planning granted } \\
\text { conditionally }\end{array}$ & $\begin{array}{l}\text { The House for an } \\
\text { Architect } \\
\text { 2007: site purchased by } \\
\text { current owner } \\
\text { 2008: planning granted } \\
\text { conditionally }\end{array}$ & $\begin{array}{l}\text { 2011: construction } \\
\text { completed }\end{array}$ \\
\hline
\end{tabular}

Table 1. The comparative development of Sites $A$ and $B$

The two sites are suitable for comparative analysis due to similarities in terms of landscape character, scale, and planning history. Both sites had pre-existing dwellings, which meant that the principle of a house on each site had already been established (a point that will be returned to in the analysis). A photograph of the realised building on the first site (A) is the sole illustration of 'Contemporary design' in Dartmoor's current Design Guide, and thus may be considered an exemplar of what planners consider "appropriate". Meanwhile three other, very different, approaches to "contemporary" design were proposed for these sites: their reception is compared.

Four separate phases of development are considered: the pre-development conditions; the first (unbuilt) design applications; the second (built) applications; and post construction

\footnotetext{
${ }^{11} \mathrm{~S}$ Belli, second interview.
} 
appraisals. This paper employs two types of discourse analysis: the analysis of direct accounts (depth interviews with key informants, including architects, planners and clients), and of written accounts (planning applications, design guides, reports, minutes of committee meetings, correspondence). We apply Deming and Swaffield's 'constructionist' approach, moving 'reflexively between the observed data and the theoretical concepts' (Deming and Swaffield 2011, 152). Findings are supported by analysis of design drawings and visits to the sites themselves.

The paper investigates the extent to which park stakeholders share common concerns and strategies or inversely whether notions of context, aesthetics and landscape experience (and the policies that govern their production) are quite distinct. In doing so we seek to clarify the relationship between landscape aesthetics and architectural preferences, specifically how landscape aesthetics are embodied in different notions of "appropriateness". Our analysis of architectural preference focuses on the three primary areas of concerndesign quality, sympathetic scale and landscape enhancement - which were identified as being key concerns during the planning process.

\section{Phase 1: Pre-Development Conditions}

Figure 2. The two sites are of a comparable size and topography. Source: Google maps, with additions from the authors.

Less than three miles apart in the south-east corner of Dartmoor National Park, the two sites are large (eight acres or more), and located away from near neighbours. Both are on sloping ground leading to deep wooded valleys, and contain a mixture of open pasture, protected woodland, and dramatic outcroppings of granite boulders characteristic of this landscape. Both sites eventually saw the development of 'bespoke' replacement dwellings. Moreover, both went through many years of design development from conceptualisation, revisions, and rejections before they were eventually completed. 
These projects are to be understood within the context of Dartmoor National Park planning processes. Lacking a central national parks administration (e.g. the USA National Parks Service), in England each national park is governed by an independent, but accountable to the national government, National Park Authority (NPA). NPAs are formed of professional planning practitioners and a lay planning committee of NPA Members, who make decisions in consultation with relevant organisations and stakeholders. The planning functions of the NPAs are designed to support the parks' statutory purposes. It is the policies within each park's own Local Plan, developed through stakeholder consultations, which form the basis for making planning decisions. The Local Plans are supported or extended in some cases by other local level documents such as Dartmoor's Design Guide.

Like many protected areas, the Dartmoor National Park Authority (DNPA) normally 'applies strong constraints' against the development of new dwellings in the open countryside (Dartmoor National Park Authority 2013, 58). It does, however, permit the replacement of existing dwellings in such circumstances under certain conditions, namely, that the replacement enhances the local environment, improves energy efficiency, and is of a scale 'sympathetic to its location' (Dartmoor National Park Authority 2013, 58). In this paper, with its focus on landscape aesthetics, we consider judgements about "sympathetic" scale and how a building can be seen to "enhance" the landscape.

The building proposed for demolition should be 'in serious disrepair', and must not be a 'candidate for inclusion on the Dartmoor National Park Historic Environment Record', thereby warranting protection due to having special architectural and/or historic interest (Dartmoor National Park Authority 2013, 58). Overall this policy position suggests the prevalence of two different approaches to architecture in the landscape; the first is that architecture is not welcome (restricting additional buildings) and the second that architecture is welcome, if it is deemed to contribute to existing landscape character, as accrued over time. 
Significantly, where a replacement dwelling is permitted, 'the increase in volume allowed over the original will be limited, and the expectation will be that permitted development rights will normally be removed' (Dartmoor National Park Authority 2013, 58). At the time of these projects the allowable increase in volume was stipulated at $10 \%$ of the volume of the existing dwelling including any outbuildings. ${ }^{12}$

Figure 3. The original bungalows on Site A (L), and Site B (R). Reproduced courtesy of Peter Hall (L), and Julian Powell-Tuck (R).

Initially, both sites contained detached, white-rendered bungalows: Site A's from the 1930 's; Site B's a Woolaway home from the 1950 's. ${ }^{13}$ In terms of size, siting and visual impact, the two dwellings were thus notably similar, but there were marked differences in the way they were valued by planners. Site A's was described as 'an attractive feature' ${ }^{14}$ by a planner who objected to the site's redevelopment, while in direct contrast, Site B's was deemed 'an eyesore' by those supporting redevelopment. ${ }^{15}$

\section{Phase 2: First Design Proposals}

\subsection{Site A. The "Voysey-Lutyens" (Unbuilt)}

Figure 4. The first design proposal (unbuilt) for Site A. Front entrance elevation. Source: Dartmoor National Park Authority, Application no.5/04/179/83/03. Drawing reproduced courtesy of Stuart Martin.

Although the existing bungalow could potentially be replaced through normal planning policy, the Site A clients' first planning application instead addressed a national planning clause, Planning Policy Guidance 7 (PPG7), also known as the "Country House Clause". This offered 'an exemption from all planning constraints for individual houses that meet

\footnotetext{
${ }^{12}$ Current policy, in the DNPA Local Plan [adopted 2013] is a 15\% increase but excludes 'detached ancillary structures'.

${ }^{13}$ Woolaway homes were part of the Government's rebuilding efforts after the end of World War II, and were often built in rural areas on large plots of land.

${ }^{14}$ Dartmoor National Park Authority, "Report of the Assistant National Park Officer (Planning and Community)", Application no. 5/04/179/98/03, September 4, 1998.

${ }^{15}$ F E Walters, letter to C Hart [DNPA Senior Planning Officer], January 20, 2004. TS.
} 
specific criteria, not least of all that they should be architecturally outstanding'. ${ }^{16}$ In other words, on the grounds of architectural merit, a scheme might be allowed to override local planning policy restrictions, specifically in this case the size limitations attached to replacement dwellings. A PPG7 planning application strategy was inherently risky, however, with few precedents and none (at that time) within a national park. ${ }^{17}$ Instead of measurable criteria, PPG7 approval depended on subjective judgements that a design was of "truly outstanding' quality and that it would also 'significantly enhance its immediate setting and wider surroundings'. 18

Figure 5. The first design proposal for Site A was unequivocally rejected by the planning committee. Source: Dartmoor National Park Authority, Application no.5/04/179/83/03. Drawing reproduced courtesy of Stuart Martin.

A planning application was made in September 1998 for a large, ashlar granite house by architect S P Martin, in a style later described as 'a sort of mishmash of Voysey and Lutyens'. ${ }^{19}$ The application's supporting statement argued that the proposal represented 'the tradition of the country house being continued', and cited Edwin Lutyens' nearby Castle Drogo as a precedent. ${ }^{20}$ The scheme, however, was harshly criticised by local residents and the local council, and was unanimously rejected by the planning committee. In 44 letters of objection (with only 6 in support), both its scale and its design were deemed highly inappropriate. ${ }^{21}$ One objector even compared it to 'a set for a Hammer Horror movie'. 22

Some objectors expressed fear that the design would set a precedent, as one described it, of 'a rash of large properties, perhaps some being converted into flats or Timeshare,

\footnotetext{
${ }^{16}$ Planning Policy Guidance 7 [PPG7] paragraph 3.21. This legislation was introduced by Environment Secretary John Gummer in 1997. It was replaced in 2004 by Planning Policy Statement 7 [PPS7] paragraph 11, and again in 2012, by paragraph 55 of the National Planning Policy Framework [NPPF].

${ }^{17}$ Since it was introduced in 1997, there has only been an average of 6 PPG7/PPS7 houses nationwide built each year.

18 Ibid.

${ }^{19} \mathrm{P}$ Hall, [architect] second personal interview with authors, November 4, 2015.

${ }^{20}$ King Sturge \& Co [Chartered Surveyors], Application no. 5/04/179/98/03, "Architectural Statement", June 22, 1998.

${ }^{21}$ Dartmoor National Park Authority, "Report of the Assistant National Park Officer".

${ }^{22} \mathrm{G}$ and $\mathrm{C}$ Keene, letter to C Jarvis [DNPA Senior Planning Officer], July 20, 1998. TS.
} 
protruding into the skyline'. ${ }^{23}$ Another commented how the 'last wilderness colonised by large and unsuitable houses is an unthinkable future' ${ }^{24}$ One objector, however, argued that because a PPG7 'will always be a subjective matter of opinion, it would be a very dangerous precedent to allow the application'. ${ }^{25}$ They also explained that it was 'illogical to claim that a new dwelling would enhance its immediate setting...when the applicant has created the immediate setting by her landscaping works' ${ }^{26}$ Indeed the clients had already caused controversy by making a sizable lake on the property, further changing the "natural beauty" of the site. ${ }^{27}$

Further objections indicated feelings of resentment as much directed against wealthy incomers as the actual design. As architect of the later realised scheme, Peter Hall, commented 'There are people in these little communities who don't want anything to change. ${ }^{28}$ At the same time he also pointedly described the fallacy of "people coming into a national park thinking they can impose urban answers, or country estate answers, or "I am big" answers'. In this case, he concluded, it was a case of the client and designer 'just not understanding the countryside. ${ }^{29}$

Because of the nature of the PPG7 criteria, much opposition to the proposal was made on stylistic grounds, although the design reflects many of the principles later set out in Dartmoor's Design Guide, such as using local and / or heritage materials and enhancing local distinctiveness by reflecting 'significant local buildings' (Dartmoor National Park Authority 2011, 102). At almost seven times (672\%) larger than the existing bungalow, the main issue was size. ${ }^{30}$ As Hall observed, 'It was too big. It wasn't horrible. That is the sort of thing that a

\footnotetext{
${ }^{23}$ B Renshaw [Secretary to the Newton Abbot Ramblers], letter to N Atkinson [DNPA Chief Executive and National Park Officer], July 29. 1998. TS.

${ }^{24}$ M W Baldwin and J Baldwin, letter to C Jarvis, July 28, 1998. TS.

${ }^{25}$ W F C Boughey, letter to C Jarvis, August 1, 1998.

${ }^{26}$ Ibid.

${ }^{27} \mathrm{P}$ Hall, first personal interview with authors, May 11, 2015.

${ }^{28} \mathrm{P}$ Hall, second interview.

${ }^{29}$ Ibid.

${ }^{30}$ Dartmoor National Park Authority, "Report of the Assistant National Park Officer".
} 
large number of people like.' One of the few letters in support of the design, however, argued that:

Size is relative; in a public prominent situation, a house like this would probably be overbearing and obtrusive. [Here] it is measured solely by the trees and the hillside that surrounds it, and [it] is designed to the scale of its setting. ${ }^{31}$

Another supporter felt that 'to be frightened to do something in case it is repeated condemns us all to a bland conformity', and 'belittles the authority of the Planning Department' ${ }^{32}$ Ultimately, however, for planners the scheme was judged to have failed 'every test of acceptability... without conserving the overall legal and policy framework which applies within a national park'. ${ }^{33}$ The Senior Planning Officer also pointed out that 'in National Parks, policies give greater priority to restraint'.34

\subsection{Site B. The "One-Eyed Slug" (Unbuilt)}

We now turn to consider the 2004 planning application by architects Andrew Wright Associates to replace the bungalow on Site B. In this instance, however, the proposal was of a very different style, employed a very different application strategy, and subsequently saw a very different outcome to the first proposal for Site A.

Figure 6. The first design proposal (unbuilt) for Site B. Source: Dartmoor National Park Authority, Application no.0978/03. Drawing reproduced courtesy of Andrew Wright.

The planning application, which describes 'an environmentally sensitive new house $\lfloor\ldots\rfloor$ nestled into the landscape', does not prepare the reader for the bold extravagance of the design, with its massive, curvilinear roof. ${ }^{35}$ Locally called the 'One-Eyed Slug', ${ }^{36}$ the scheme

\footnotetext{
${ }^{31} \mathrm{~W}$ and V Kidner, letter to the Dartmoor National Park Authority, August 6, 1998. TS.

${ }^{32}$ Ibid.

${ }^{33}$ Dartmoor National Park Authority, "Report of the Assistant National Park Officer".

${ }^{34}$ C Jarvis, letter to King Sturge \& Co, April 23, 1998. TS.

35 Andrew Wright Associates, "Summary Information", Application no. 0978/03, December 17, 2003.

${ }^{36}$ J Powell-Tuck [architect], personal interview with authors, November 4, 2015.
} 
proved highly controversial both in terms of its unusual design and its large scale. ${ }^{37}$ The planning committee, however, praised it as 'an exciting form of modern, sustainable development, replacing a group of buildings which could, at best, only be described as mediocre'. ${ }^{38}$ As the Director of Planning at the time explained:

There is a widely-accepted view that National Park landscapes are not landscapes "set in aspic" that are to be protected at all costs, but they are places in which good things, even experiments, can be allowed to happen [...] there will be occasional cases where the "rule book" may not be the overriding factor when something genuinely innovative and exciting is being proposed. ${ }^{39}$

This design certainly overturned the park's "rule book" (as articulated in the later Design Guide) by using modern materials and making no references to vernacular architecture. A significant factor in its acceptance appears to be that, unlike Site A, the planners disliked the existing bungalow, and saw this proposal as an opportunity to remove it, thus "enhancing" the site. The proposal also addressed local planning policy on permitted development, rather than attempting to override it through PPG7. Despite controversy over the design, it was granted planning permission, although concerns over the visual impact of glare led to the condition that non-reflecting glass should be used (although the building was permitted to be white). ${ }^{40}$

In allowing this scheme, the planners were much criticised, not only by objectors who disliked the design, but also for being 'extremely generous' in calculating the building's acceptable volume. ${ }^{41}$ The Parish Council commented that 'the rules about the size of the footprint had been somewhat stretched, literally, by allowing all sheds, however small, to be

\footnotetext{
${ }^{37}$ H Gould [Parish Council Chairman], letter to G Wall, [DNPA Director of Planning and Community], March 9, 2004. TS.

${ }^{38} \mathrm{G}$ Wall, letter to H Gould, March 16, 2004. TS.

${ }^{39} \mathrm{G}$ Wall, letter to J Paxman, April 21, 2004. TS.

${ }^{40}$ Dartmoor National Park Authority, "Grant of Conditional Planning Permission", Application no. 0978/03, September 30, 2004.

${ }^{41}$ J. Hewison, letter to N Atkinson [DNPA Chief Executive and National Park Officer], March 10, 2004. MS.
} 
included', and it was felt that this demonstrated that 'there is one rule for the rich and another for everyone else'. ${ }^{42}$ This was refuted by the Director of Planning, who replied that 'each proposal, regardless of its scale, must be considered on its merits and the identity, or wealth, of the applicant is irrelevant'. ${ }^{43}$ In a later letter however he argued that, as part of Dartmoor's cultural heritage:

There have always been wealthy individuals [...] who have been able to make bold architectural statements, which, in their day, were often controversial, but which have come to be accepted as valued parts of a varied landscape. ${ }^{44}$

In the end, however, the project, which was wrought with technical difficulties, proved too expensive to construct, and the site was sold on, but with approved planning consent in-situ.

\section{Phase 3: Second Design Proposals}

\subsection{Site A. The "Underground House" (Built)}

Figure 7. The second (built) proposal for Site A, by Van der Steen Hall Architects. Photo reproduced courtesy of Peter Hall.

Returning to Site A: after their first proposal was refused, and no doubt prompted by the hostility with which their previous application had been received, the clients discarded all notions of having 'a big grand house'. ${ }^{45}$ They engaged a new architect, Peter Hall, of Van der Steen Hall Architects, to design a house which people and planners would accept. The new brief was simple: 'a house that no one could see' ${ }^{46}$ Tucked into the hillside and following its contours, the executed building is designed to seamlessly merge with the landscape such that sheep can wander about on the turf roof. Its eastern elevation, in contrast, opens across the

\footnotetext{
${ }^{42}$ H. Gould, letter to G. Wall.

${ }^{43} \mathrm{G}$ Wall, letter to H Gould.

${ }^{44} \mathrm{G}$ Wall, letter to J Paxman.

${ }^{45} \mathrm{P}$ Hall, second interview.

${ }^{46}$ Ibid.
} 
valley with a double row of colonnaded windows affording light and views into the deceptively spacious and vaulted interior.

Figure 8 The "Underground House" from the rear. Photo reproduced court esy of Peter Hall.

As well as visibility, the other key factor influencing this design was size. To comply with local policy, it was considerably smaller than the rejected proposal. It proved, however, that having decided that they would support this latest design, the planners, (as with the "One-Eyed Slug"), took a flexible approach to the $10 \%$ policy on volume. The architect described how, the planners "were going to help [the client] have as large a house as possible, under the rules, so long as he stuck with this intention' ${ }^{47}$ Response to the application was mixed, with 10 letters of support (e.g. 'an architectural enrichment of the area') and 6 letters of objection, one of which described it as 'a military fortification', ${ }^{48}$ a comment indicating that "camouflaging" a building could be read not only as a gesture of modesty but also as a gesture of subversion. Criticisms over size were refuted on the grounds that although the new house was somewhat larger in volume than the existing bungalow, the visible volume (i.e. volume above ground level) was less. ${ }^{49}$

Figure 9. From some angles, the 'Underground House' almost disappears into the landscape. Photo reproduced courtesy of Peter Hall.

The planners took the view that:

Although it would not be a 'traditional' Dartmoor development, it will reduce the overall visual impact of the development, as existing, and be a fine example of modern, sustainable architecture in a location where an innovative design solution will not be out of place. ${ }^{50}$

Planning permission was granted in December 2001.

\footnotetext{
${ }^{47}$ Ibid.

${ }^{48}$ Dartmoor National Park Authority, "Committee Report", Application no. 0563/01, November 2, 2001.

${ }^{49}$ Ibid. The new roof line was deliberately designed to be lower than that of the original bungalow, and the bedrooms were all sunk lower than the bungalow's under-croft.

${ }^{50}$ Ibid.
} 
Despite comments that 'there are still people on the planning committee who think that "Tudorbethan" is a sort of safe answer" ${ }^{51}$, it seems again in this instance, as with the "One-Eyed Slug", that the notion of contemporary design was not unwelcome to planners, albeit with the implication that there are sites where "an innovative design solution" would be considered "out of place. Even so, this study reinforces the idea that, for planners, an unseen building is a good building.

\subsection{Site B: The "House for an Architect" (Built)}

Figure 10 The second (built) proposal for Site B, designed by Powell Tuck Associates. The steps in blocks down the sloping site, addressing both the upper meadow and the lower woodland. Photo by Edmund Sumner Photography, reproduced courtesy of Edmund Sumner.

Site B, with its in-situ planning consent for a sizable contemporary building, attracted the attention of London architect Julian Powell-Tuck. During pre-application consultations, he explained to planners his wish 'to demonstrate that a new contemporary house can be carefully integrated into a special landscape with a minimum of impact'. ${ }^{52}$ The planners, however, focused on size rather than design or environmental qualities, stipulating that the scale of the proposed dwelling must relate to the existing bungalow, not the approved "OneEyed Slug". 53 As with the "Underground House", however, it would be "the above ground volume which is the visual part of the building and that which will form the basis of assessing its impact' ${ }^{54}$ This gave the architect an opportunity to create a larger dwelling by again burying part of it in the ground.

Figure 11 The "House for an Architect", concept sketch by Powell Tuck Associates, reproduced courtesy of Julian Powell-Tuck.

Although the new design was driven by the relationship of the building to landscape and by energy efficiency, ${ }^{55}$ the application sets out in great detail the strategies by which it

\footnotetext{
${ }^{51} \mathrm{P}$ Hall, second interview.

52 J Powell-Tuck, e-mail message to C Hart, December 3, 2007.

${ }^{53}$ C Hart, e-mail message to J Powell-Tuck, December 4, 2007.

${ }^{54} \mathrm{C}$ Hart, letter to J Powell-Tuck, February 12, 2008. TS.

${ }^{55} \mathrm{~J}$ Powell-Tuck, personal interview with authors, November 4, 2015.
} 
would be 'less visually intrusive' than the accepted scheme, being 'modest in its external manifestation', 'masked by the trees', and using the slope of the ground to 'conceal its volume'. ${ }^{56}$ The proposal also situates itself (somewhat ambiguously) within local tradition, being 'influenced by vernacular stone buildings and earthworks' such that it 'will seem both ancient and modern'. 57

Figure 12 Front entrance. Photo by Edmund Sumner Photography, reproduced courtesy of Edmund Sumner.

Judged by planners to be a 'bold and modern' proposal, 'using traditional materials and finishes', the scheme was awarded planning consent without objections. ${ }^{58}$ In their report, however, the focus was again on issues of visibility and the opportunity of removing the bungalow:

While it does not have the dramatic impact of that previously approved it should sit comfortably within this woodland setting and offers a real opportunity to remove a visible and unattractive building from a ridgeline location. Protection of the woodland setting and appropriate additional landscaping should allow the dwelling to blend with its surroundings. ${ }^{59}$

Figure 13 The lower part of the house addresses the surrounding woodland. Photo by Edmund Sumner Photography, reproduced courtesy of Edmund Sumner.

\section{Phase 4: After Completions}

There are post-construction narratives which pertain to each of these projects which demonstrate how just as projects change, so too do the way they are perceived. The architect took evident pleasure in recounting how, on a visit by the Planning Committee to the "Underground House" ("so that they could see that buildings could be modern'), ${ }^{60}$ one of the 'vociferous objectors' not only changed his mind, but publicly admitted that he had been

\footnotetext{
${ }^{56}$ J Powell-Tuck, "Application for Full Planning Permission", Application no. 0267/08, April 4, 2008.

${ }^{57}$ Ibid.

${ }^{58}$ Dartmoor National Park Authority, “Committee Report", Application no. 0267/08, June 27. 2008.

${ }^{59}$ Ibid.

${ }^{60} \mathrm{P}$ Hall, second interview.
} 
'wrong' in his objections. ${ }^{61}$ The acceptance of this building by planners is certainly indicated by the use of its image in the Dartmoor Design Guide. ${ }^{62}$ The fact however that no caption or accompanying text is provided with the photograph, however, also illustrates the difficulties in articulating "good" design.

In contrast, while no formal objections were raised against the "House for an Architect" during the planning process, this researcher has identified negative local opinions about the completed design, indicating a further split between locals, planners and architects. The Director of Planning seemed aware of this local feeling when he remarked on the 'antagonism from the community on that [project]'. ${ }^{63}$ The architect similarly commented how 'the trouble with around here is that anything modern $[\ldots]$ is usually treated by people as if it's the worst thing that could happen and the immediate reaction is antagonistic' ${ }^{64}$ Again, like the preference for 'Tudorbethan', this reflects how designers' preferences towards contemporary design often remain at odds with the non-design public, including some planners.

\section{Discussion}

Landscape theories and policies, as evidenced by the European Landscape Convention, are increasingly recognising the complexity of landscape and moving away from a purely visual approach. This research has confirmed, however, in English national parks, landscape aesthetics (often associated with a "rural idyll") continue to play a dominant role in landscape planning and are instrumental in shaping notions of "appropriate" architecture. These notions, moreover, are often in tension, despite a consensus among planners and the wider public that

\footnotetext{
61 Ibid.

${ }^{62}$ See Fig. 7.

${ }^{63} \mathrm{~S}$ Belli, first personal interview with authors, October 10, 2015.

${ }^{64} \mathrm{~J}$ Powell-Tuck, interview.
} 
human interventions should be designed to be visually "in harmony" with park landscape character.

These case studies have revealed considerable aesthetic frictions among residential architecture discourses, and have drawn out many conflicting stakeholder "landscape" positions, for example between experts and non-experts, and between the practical / political concerns of locals and the landscape idealisation of non-local clients. Views on development ranged from resisting all new buildings, architects wanting to have more freedom to design contemporary work, to people wanting to realise their dream home. A summary of the key issues impacting stakeholders' notions (and policy definitions) of "appropriate" design, and their relative significance (represented by the size of the $\mathrm{X}$ ) is presented here: ${ }^{65}$

\begin{tabular}{|l|l|l|l|l|}
\hline & Scale and size & Visibility & $\begin{array}{l}\text { Landscape } \\
\text { enhancement }\end{array}$ & $\begin{array}{l}\text { Design quality incl. } \\
\text { "contemporary" }\end{array}$ \\
\hline Locals (average) & $\mathbf{X}$ & $\mathrm{x}$ & $\mathrm{x}$ & $\mathbf{X}$ \\
\hline Clients & $\mathbf{X}$ & - & - & $\mathbf{X}$ \\
\hline Architects & $\mathbf{X}$ & $\mathrm{X}$ & $\mathrm{X}$ & $\mathbf{X}$ \\
\hline Planners & $\mathbf{X}$ & $\mathbf{X}$ & $\mathbf{X}$ & $\mathbf{X}$ \\
\hline Policy & $\mathbf{X}$ & $\mathbf{X}$ & $\mathbf{X}$ & $\begin{array}{l}- \\
\text { (at the time) }\end{array}$ \\
\hline
\end{tabular}

Table 2 Stakeholder issues surrounding notions of "appropriate" design arising from case study analysis

Scale and size, landscape enhancement and design quality (including "contemporary" design) will each be discussed in turn. "Visibility" impacted on notions of both scale and enhancement and will be discussed accordingly.

\subsection{Scale and size}

The most significant planning issue was scale and size. Strikingly, all three applications that complied with local policy on permitted volume were granted planning permission, including

\footnotetext{
${ }^{65}$ Table format adapted from Butler $(2016,246)$.
} 
the controversial "One-Eyed-Slug". In contrast, the "Voysey-Lutyens" application, made under PGG7, and which fulfilled many of the criteria in the design guidance (except size) was overwhelmingly rejected.

As the table shows, scale and size were highly significant among all stakeholder groups. The way these issues were interpreted by such groups, however, varied widely. For planners, scale was inherently connected to visual prominence. Although replacement dwelling policy imposes specific quantitative measures on scale, for planners such measurements could be flexibly interpreted based on "visible volume". This indicates that planning practice is not in accord with planning policy on this issue. Indeed, the Director of Planning explained that this policy likely to be reviewed. 'Planning', he commented 'is too grey an area' for 'volumetric' policies, and judgements should be made based on 'good design' and whether 'it complements the existing'. ${ }^{67}$ The danger, however, for inconsistency if such judgements are left entirely to interpretation can be seen from the criticism this "flexibility" generated from some locals.

The architects similarly felt judgments about scale should be based on design qualities, assessed on a site by site basis, rather than relying on quantitative figures. As one explained, 'Architecture often falls down on its ability to merge or work with landscape', ${ }^{68}$ a comment suggesting that a poorly merged structure will "fail" regardless of its size. For the architects, factors such as sensitive siting, local materials, naturalistic landscaping, or even putting some of the building into the ground were more important in helping a design "fit in" than quantitative measurements. It was suggested by one architect that quantitative policy may, in fact, get 'in the way of someone doing the right thing on the right site'. 69

\footnotetext{
${ }^{66} \mathrm{~S}$ Belli, second interview.

67 Ibid.

${ }^{68} \mathrm{~J}$ Powell-Tuck, interview.

${ }^{69}$ Ibid.
} 
For some, scale and size invoked non-visual values, particularly "gentrification", associated with a loss of affordable housing and an influx of "wealthy" incomers. For others, in contrast, "larger" houses were positively associated with an increase in value of the overall building stock. Meanwhile, clients, as the Director of Planning explained, wanted to make the most of [a] site as a resource', and he pointed out the fallacy of restricting replacement dwelling size on the grounds of retaining a stock of affordable houses, given that (particularly on large sites) 'even small buildings on Dartmoor are not truly affordable'. ${ }^{70}$ There is a 'dilemma', as he put it, for planners to fit 'a demanding brief by the client into this landscape' ${ }^{71}$ This could be said to apply equally to the architects.

\subsection{Design "quality" including "contemporary" design}

Architects, clients and locals all expressed strong views about design "quality". Local opinion was particularly evident in the case of the PPG7 application. Design "quality", however, although often iterated as a term, is not clearly defined in local policy. Planners, perhaps reflecting this ambiguity, as well as an unwillingness 'to make it prescriptive', ${ }^{72}$ seemed much less willing than other stakeholders to express judgements of design quality. Certainly, throughout this research, architects raised the issue of expertise in making assessments of quality, and spoke of the difficulty of communicating design ideas through drawings, particularly in a context where there is "no one with design training' on the planning team. ${ }^{73}$ This was particularly evident among Committee Members, who, according to Hall, 'often are not in a position to comment' on design, and instead 'defer to the paid officers' to do so. ${ }^{74}$

Contemporary design proved divisive in all cases. Many residents appeared to find it wholly "inappropriate". The Director of Planning explained that many 'lay people' on the

\footnotetext{
${ }^{70} \mathrm{~S}$ Belli, second interview.

${ }^{71}$ Ibid.

${ }^{72}$ Ibid.

${ }^{73} \mathrm{~S}$ Belli, first interview.

${ }^{74} \mathrm{P}$ Hall, first interview.
} 
Planning Committee preferred architecture that fell within their traditional 'comfort zone', 75 or "Tudorbethan" as one architect described it. ${ }^{76}$ While a "contemporary" building might be 'a very difficult concept', there seems to be a desire on the part of the DNPA to work through 'how to get contemporary, modern, $21^{\text {st }}$ century design into a landscape like this [...] and get people to accept it ${ }^{77}$; the Director of Planning believed the key to this would be a "compromise" position of "quality architecture which respects the setting and landscape of Dartmoor using a contemporary design that celebrates the old and the new'. ${ }^{78}$ So long as a design fulfilled the other development criteria, however, it was clear that some planners were prepared to take design "risks" in approving very "contemporary" schemes.

Meanwhile like "quality", "contemporary" design was not (at the time) articulated in local policy, and even in the later Design Guide there remains a clear gap between wider design discourses and the policy guidance. Here, rather than a response to landscape features or character, architecture is more often expressed in terms of a reinterpretation of the forms and materials of local vernacular traditions. Environmental sustainability was similarly not a dominant planning narrative for this type of housing, or in the design guidance, although sustainable environmental performance was a core value driving both the proposals on site B. Again, the Director of Planning seemed aware of these omissions when he suggested that in the next iteration of the "Design Guide" there was a need "to do a little more work on what do we mean by sustainable build, and what do we mean by good contemporary design' ${ }^{79}$

\subsection{Landscape enhancement}

The third key issue, both in accordance with statutory requirements and the significance of landscape aesthetics in this context, was the ability of a proposed building to "contribute" to

\footnotetext{
${ }^{75} \mathrm{~S}$ Belli, second interview.

${ }^{76} \mathrm{P}$ Hall, second interview.

${ }^{77} \mathrm{~S}$ Belli, first interview.

${ }^{78} \mathrm{~S}$ Belli, e-mail message to authors.

${ }^{79} \mathrm{~S}$ Belli, second interview.
} 
landscape character, specifically, whether buildings should be seen in rural landscapes, and what their presence contributes to those landscapes. Elements of all these projects reinforce the assumption that, in national parks 'new development invariably has a negative visual impact, and thus should be designed to "disappear" into the landscape' (Land Use Consultants 2001, 8).

The emphasis of park planners was certainly less on how to "enhance" landscape and more on preventing its disfiguration. As with scale, for planners, landscape enhancement was linked to judgements of visibility, which was generally perceived as negative. In contrast, for designers, visibility could be positive and a new building could 'enhance' a site, in the sense of increasing its quality and value. The architect for the "Underground House" took pains to emphasise that the idea to 'bury the house', came not from him, but from the clients as a reaction to the rejection of their first application. ${ }^{80}$

Instead, it seemed that for planners, in the case of replacement dwellings, the decisive factor was not so much a perceived positive relationship of a new building to its setting but the perception of "improving" the site relative to its previous condition. This can be clearly seen for example in the contrasting perceptions of the two original bungalows, which, despite their similar appearances, were valued very differently depending on whether the notion of a replacement was welcome. It was also clear from the design statements (written by the architects) which explicitly and favourably compared the visual impact of the proposals to that of their precedents, that the architects understood the significance of "improvement" in achieving planning permission. Indeed, for planners, enabling some forms of change could even be interpreted as "preserving" landscape from "less appropriate" forms of change.

\subsection{Whose values are represented?}

\footnotetext{
${ }^{80} \mathrm{P}$ Hall, second interview.
} 
Design 'has always realized a particular society's, even a particular person's, attitudes toward space and nature' (Hunt 1992, 133). These case studies have indicated that while stakeholder position is significant in shaping stakeholder values, these positions are complex. The park planning process, which inevitably promotes the values of one group over another, has been argued to be 'based on professionals' outsider based values missing the intimacy and subjectivity of the insiders who directly experience the landscape' (Butler 2016, 240). This research, however, has shown that planners, in negotiating between the rights and aspirations of freeholders and the democratic interests of a wider public, can employ subjective judgments in interpreting both design and policy. Differences have also emerged between planning officers, representing "professional outsiders" and Committee Members, who are non-professionals (in terms of design) and often insiders themselves. Planners are only 'one part of the jigsaw', and the 'more controversial [...] particularly the contemporary' proposals 'very often end up in Planning Committee'. 81

These proposals all represent bespoke private housing commissioned by "outsiders", in contrast to existing local housing stock and residential communities. Local architects, it was suggested, as both "insiders", and "experts", had a role to play in shaping the values of their "outsider" clients who "bring a whole lot of ideas and feelings and beliefs, attitudes and requirements', which were 'not necessarily a very easy match' with Dartmoor. ${ }^{82}$ Particularly, it was explained, when such clients 'want a grand house' $\lfloor\ldots\rfloor$ we generally imbue them with a slightly different set of values [because] what they're asking for we don't feel is appropriate ${ }^{83}$ Other architects, however, as non-locals, were criticised for not understanding what was "appropriate" in this landscape, and designing unsuitable buildings (for example the "Voysey-Lutyens").

\footnotetext{
${ }^{81} \mathrm{~S}$ Belli, second interview.

${ }^{82} \mathrm{P}$ Hall, first interview.

${ }^{83} \mathrm{P}$ Hall, first interview.
} 


\section{Conclusion}

English national park planning is policy-led, and there are both qualitative and quantitative methodologies around which decisions are made. It was clear from these case studies that having a meaningful discussion about design practice in Dartmoor cannot take place without planning rules and values arising too, which frame the way the designers position their work.

There is an inherent flexibility within the park planning system which allows for judgements about landscape change, including development and architectural design, to be made on a site by site basis. This means that the subtleties of rural landscape setting and character and as well as ecological and social context (for example neighbouring properties and landscape uses) can be considered. The architects emphasised the importance of an intuitive response to a site, or as Hall put it 'just a feeling for where you are and what's best in the circumstances'. ${ }^{84}$ The implication that someone would intuitively recognise "what's best" highlights a further potential split between the cultural landscape as conceptually constructed by planners / stakeholders and designers practicing within it, where such 'intuition' will arise as a result. The effects of this friction extend beyond park landscapes and could be applied to the assessment of design quality and contextualisation in any context.

Meanwhile the price paid for such flexibility is a lack of consistency around key terms and concepts within the planning and design discourse, and a perceived inconsistency in the planning process itself, adding to development tensions amongst stakeholders. It also suggests that rural landscape change is difficult to predict, and indeed the Director of Planning commented that if he had 'wanted certainty' he 'would have been a building inspector not a planner' ${ }^{85}$ In this study of "appropriate" architecture, there were evident discrepancies in interpretations of scale and size, visibility, landscape enhancement and

\footnotetext{
${ }^{84} \mathrm{P}$ Hall, first interview.

${ }^{85} \mathrm{~S}$ Belli, second interview.
} 
design "quality" among stakeholders. Similar buildings were evaluated differently, while one which was celebrated as enhancing the landscape could also be decried for destroying it.

Such inconsistencies appear to be due to several factors, including the substantive and complex nature of landscape itself, around which stakeholders formed different assumptions and perceptions. There is also an inherent difficulty in objectively defining "quality" in architectural terms and communicating design ideas. Current planning policy does not reflect the complexity of the planning process, which could be attributed to its 'trying to be too prescriptive' and being 'sort of stuck in the past' ${ }^{86}$ While it is not yet clear how, as Olwig $(2007,581)$ asks, are we 'to analyze and plan' a landscape of such 'changeable cultural perceptions', this research has shown that understanding the tensions amongst different landscape aesthetics can provide valuable insight into understanding frictions over architectural design. Indeed, the application of a "landscape aesthetic" approach to discourse, identifying a site's immediate and wider character and value across all stakeholders, and setting out the implications for architectural design, could improve landscape understanding in relation to architecture and reduce frictions around the design and planning of new dwellings. In any event, the successful and "appropriate" application of innovative design in a sensitive environment such as Dartmoor, hinges upon having a meaningful dialogue between all parties - residents, planners, clients and designers - which an engagement with ideas about landscape aesthetics and architectural design, could facilitate.

\section{Acknowledgements}

This ongoing research is supported by a studentship at the University of Nottingham. An earlier version of this paper was presented at the Reading Architecture Across the Arts and Humanities conference at the University of Stirling, supported by the AHRC. Many thanks to architects Peter Hall, Julian Powell-Tuck, Stuart Martin and Andrew Wright, to Stephen Belli and his staff at the Dartmoor National Park Authority, and to all who commented on this work.

\footnotetext{
${ }^{86}$ Ibid.
} 


\section{References}

Belcher, Elizabeth H., and J. Douglas Wellman. 1991. "Confronting the Challenge of Greenline Parks: Limits of the Traditional Administrative Approach." Environmental Management 15 (3):321328.

Blunden, John, and Nigel Curry, eds. 1989. A People's Charter? Forty Years of the National Parks and Access to the Countryside Act, 1949. Cheltenham: Countryside Commission.

Butler, Andrew. 2016. "Dynamics of integrating landscape values in landscape character assessment: the hidden dominance of the objective outsider." Landscape Research 41 (2):239-252. doi: 10.1080/01426397.2015.1135315.

Carr, Ethan. 1998. Wilderness By Design: Landscape Architecture and the National Park Service. Lincoln and London: University of Nebraska Press.

Carr, Ethan, Shaun Eyring, and Richard G. Wilson, eds. 2013. Public Nature: Scenery, History, and Park Design: University of Virginia Press.

Dartmoor National Park Authority. 2011. Dartmoor National Park Design Guide. Bovey Tracey, Devon: Dartmoor National Park Authority.

Dartmoor National Park Authority. 2013. Development Management and Delivery Development Plan Document. Bovey Tracey, Devon: Dartmoor National Park Authority.

Deming, M.E., and S. Swaffield. 2011. Landscape Architectural Research: Inquiry, Strategy, Design. London: Wiley.

Dinnie, Elizabeth, Kirsty L. Blackstock, and Rachel Dilley. 2012. "Landscapes of Challenge and Change: Contested Views of the Cairngorms National Park." Landscape Research 37 (4):451-466. doi: 10.1080/01426397.2012.696598.

Donovan, Kevin, and Menelaos Gkartzios. 2014. "Architecture and rural planning: "Claiming the vernacular'." Land Use Policy 41:334-343. doi: 10.1016/j.landusepol.2014.06.013.

Dudley, Nigel, ed. 2008. Guidelines for applying protected area management categories. Gland, Switzerland: IUCN.

Hunt, John Dixon. 1992. "Reading and Writing the Site." In Theory in Landscape Architecture: A Reader, edited by Simon Swaffield, 131-136. Philadephia: University of Pennsylvania Press.

Jorgensen, Anna. 2011. "Beyond the view: Future directions in landscape aesthetics research." Landscape and Urban Planning 100 (4):353-355. doi: 10.1016/j.landurbplan.2011.02.023.

Kelly, Matthew. 2015. Quartz and Feldspar: Dartmoor - A British Landscape in Modern Times. London: Vintage Publishing.

Land Use Consultants. 2001. Development Planning Control in National Parks in England and Wales. Edinburgh: Scottish Executive

Leonard, Patrick. 2007. "National parks today: why do we need them." Landscape Research 10 (1):25-28. doi: 10.1080/01426398508706136.

Lloyd, Greg, John McCarthy, and Barbara Illsley. 2004. "Commercial and industrial developments in national parks in England and Wales: Lessons for the Scottish agenda." Journal of Environmental Policy \& Planning 6 (3-4):289-304. doi: 10.1080/1523908042000344078. 
Lowe, Philip, Jonathan Murdoch, Neil Ward, and Terry Marsden. 2003. The Differentiated Countryside. Abingdon: Routledge.

MacEwen, Ann, and Malcolm MacEwen. 1987. Greenprints for the Countryside: The Story of Britain's National Parks. London: Allen and Unwin.

MacEwen, Ann, and Malcolm MacEwen. 1982. National Parks: Conservation or Cosmetics. London: George Allen \& Unwin.

Matless, David. 1998. Landscape and Englishness. London: Reaktion Books Ltd.

Murdoch, Jonathan, and Philip Lowe. 2003. "The Preservationist Paradox: Modernism, Environmentalism and the Politics of Spatial Division." Transactions of the Institute of British Geographers, New Series 28 (3):318-332. doi: 10.1111/1475-5661.00095.

Olwig, Kenneth R. 2002. Landscape, Nature, and the Body Politic: From Britain's Renaissance to America's New World. Madison: University of Wisconsin Press.

Olwig, Kenneth R. 2007. "The Practice of Landscape 'Conventions' and the Just Landscape: The Case of the European Landscape Convention." Landscape Research 32 (5):579-594. doi: $10.1080 / 01426390701552738$.

Porteous, Douglas J. 1996. Environmental Aesthetics: Ideas, Politics and Planning. London: Routledge.

Richards, Francesca, and Madhu Satsangi. 2004. "Importing a policy problem? Affordable housing in Britain's National Parks." Planning Practice and Research 19 (3):251-266. doi: 10.1080/0269745042000323201.

Selman, Paul. 2010. "Landscape planning - preservation, conservation and sustainable development." Town Planning Review 81 (4):381-406. doi: 10.3828/tpr.2010.13.

Selman, Paul, and Carys Swanwick. 2010. "On the Meaning of Natural Beauty in Landscape Legislation." Landscape Research 35 (1):3-26. doi: 10.1080/01426390903407160.

Swanwick, Carys, and Land Use Consultants. 2002. Landscape character assessment: Guidance for England and Scotland. Cheltenham and Edinburgh: Countryside Agency and Scottich Natural Heritage.

Thompson, Nicola, Guy Garrod, and Marian Raley. 2013. "Planning in England's National Parks " 5th Symposium Conference Volume for Research in Protected Areas, Mittersill

Thompson, Nicola, Marian Raley, Guy Garrod, and Terry Carroll. 2014. Planning in England's National Parks: Ensuring Quality Sustainable Development? Newcastle University: National Parks England.

Tudor, Christine, and Natural England. 2014. An Approach to Landscape Character Assessment. Natural England.

Upton, Dell. 1983. "The Power of Things: Recent Studies in American Vernacular Architecture." American Quarterly 35 (3):262-279. doi: 10.2307/2712651. 


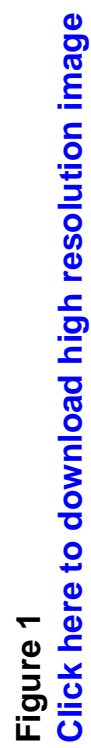




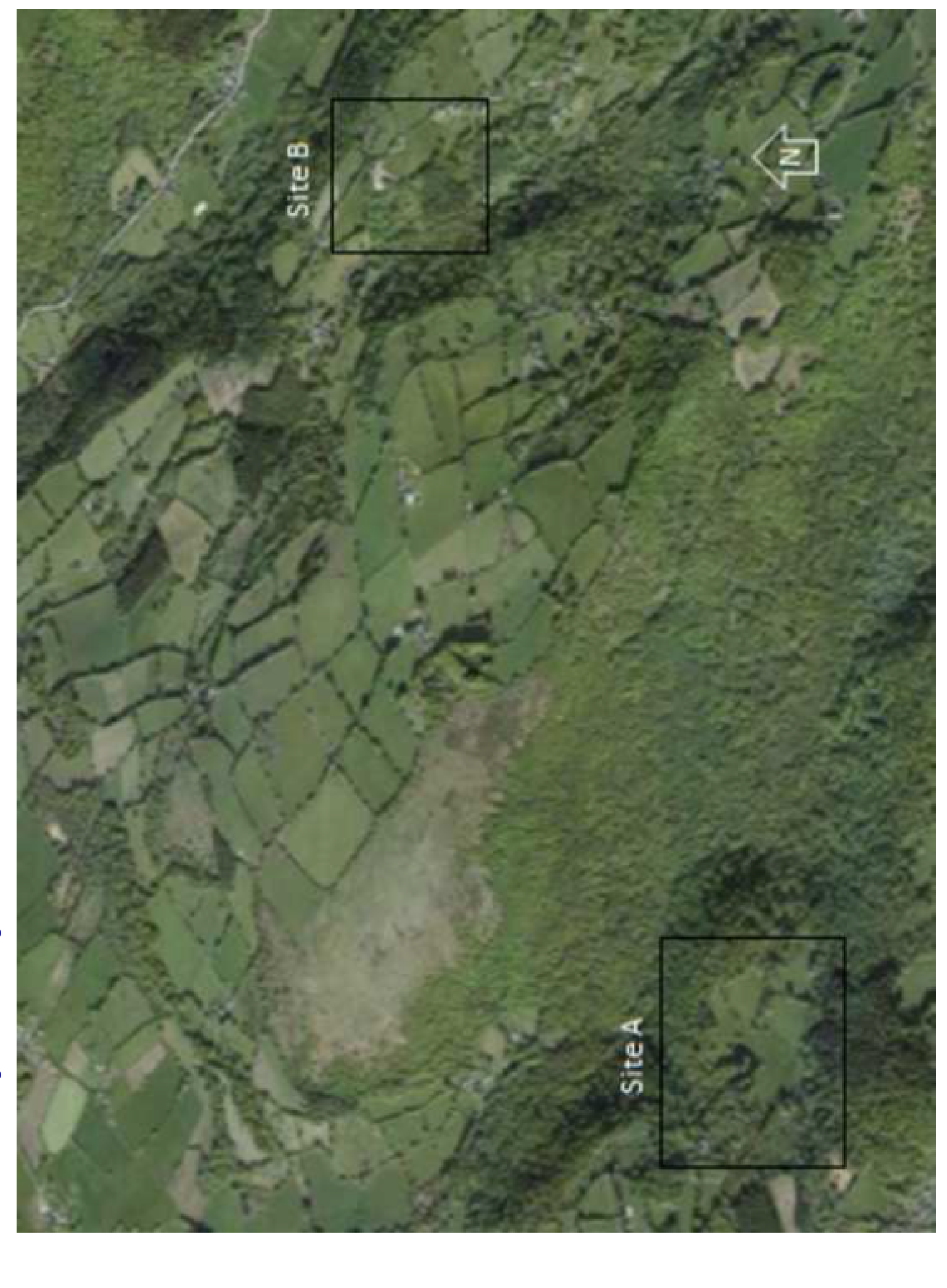


0
0
$\frac{\sigma}{0}$

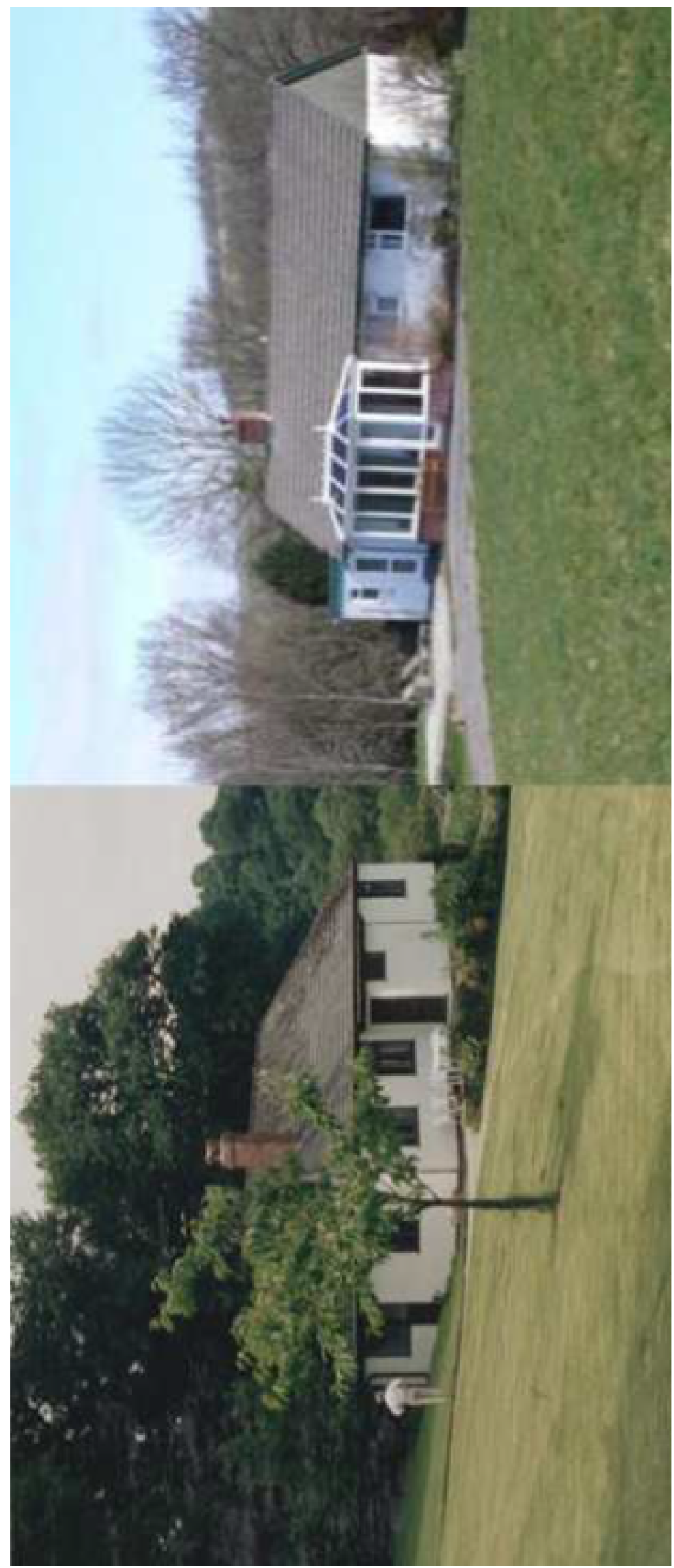




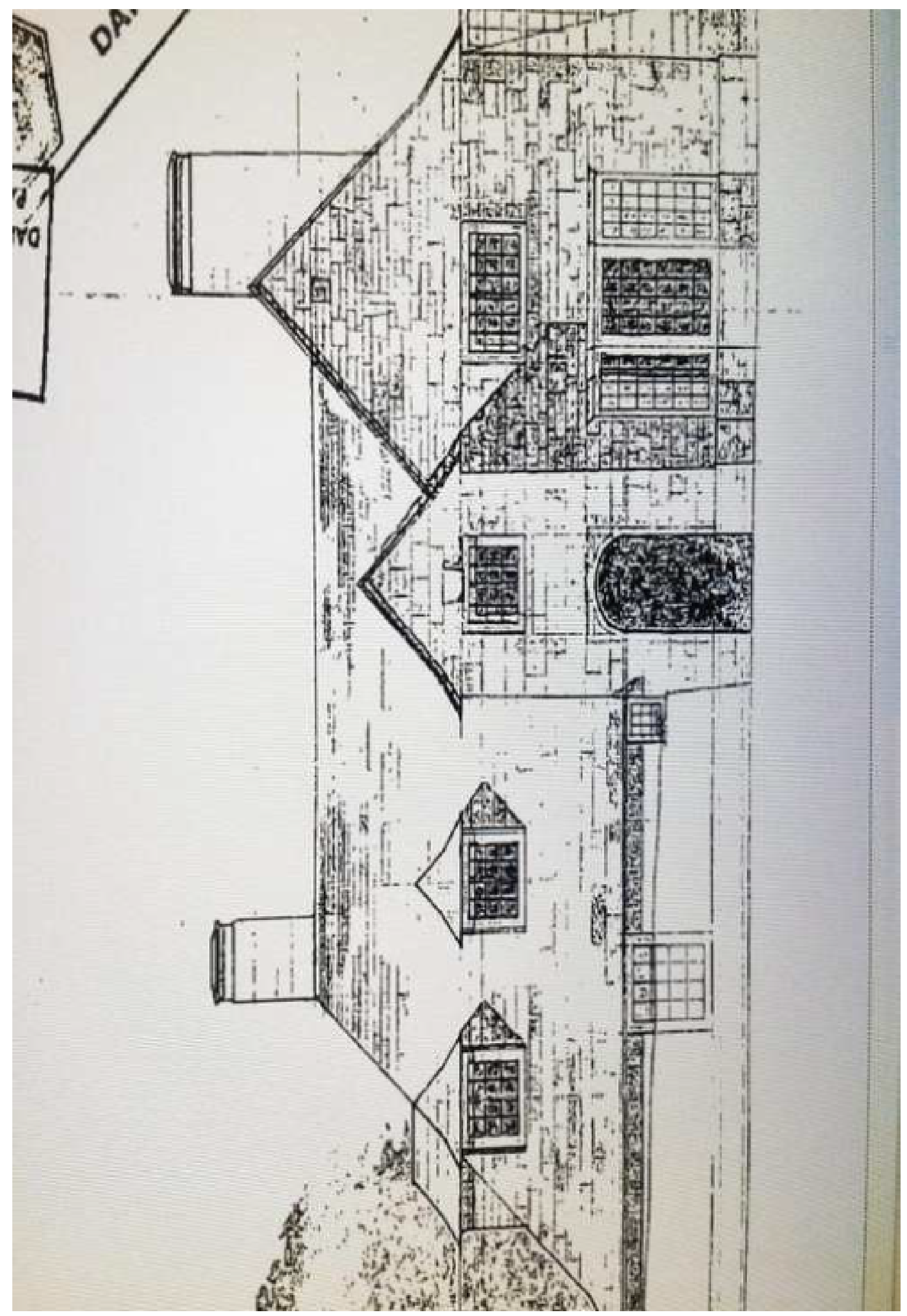




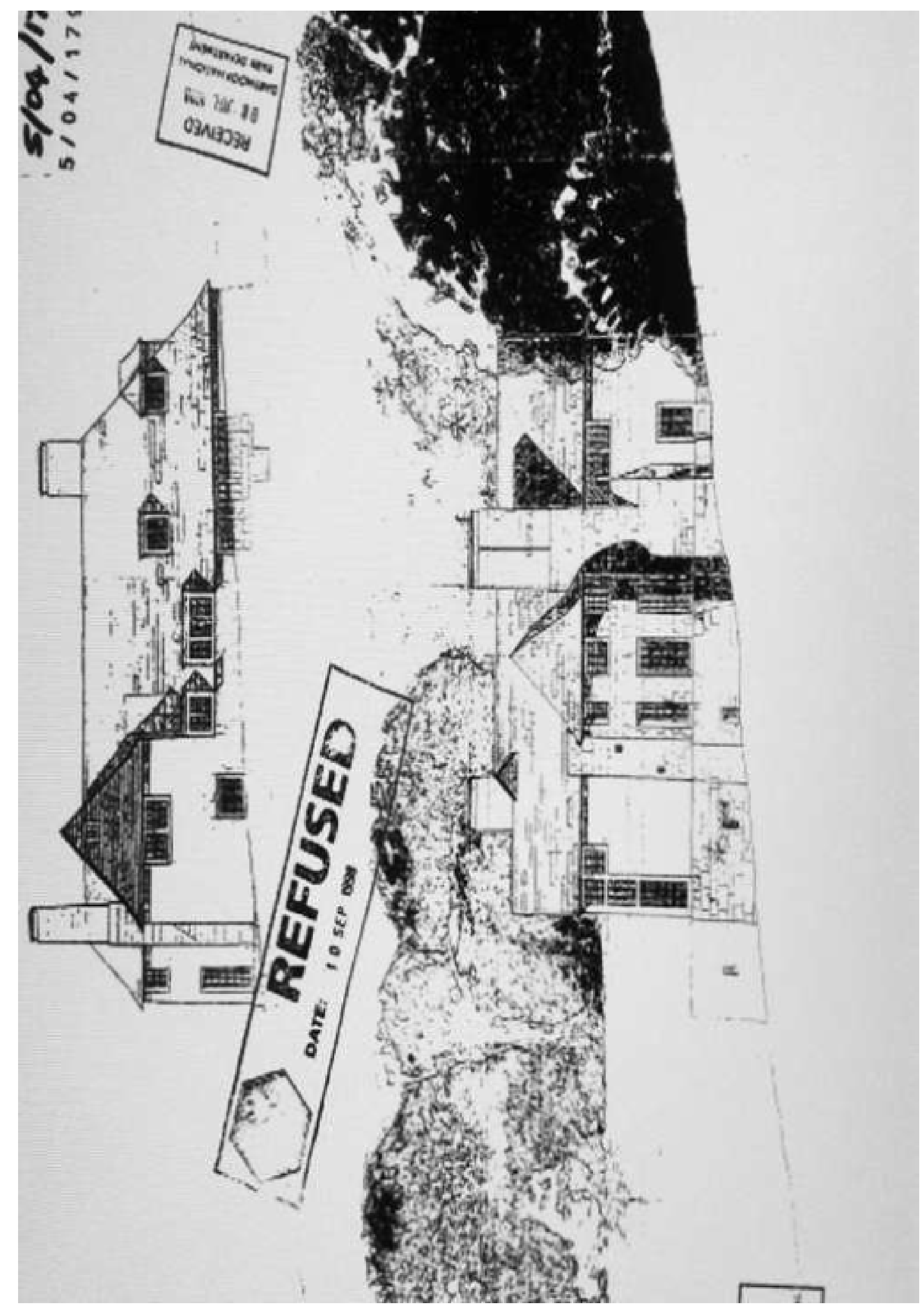

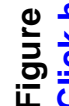




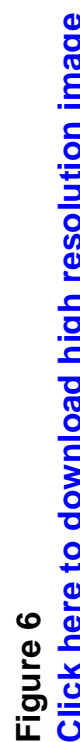

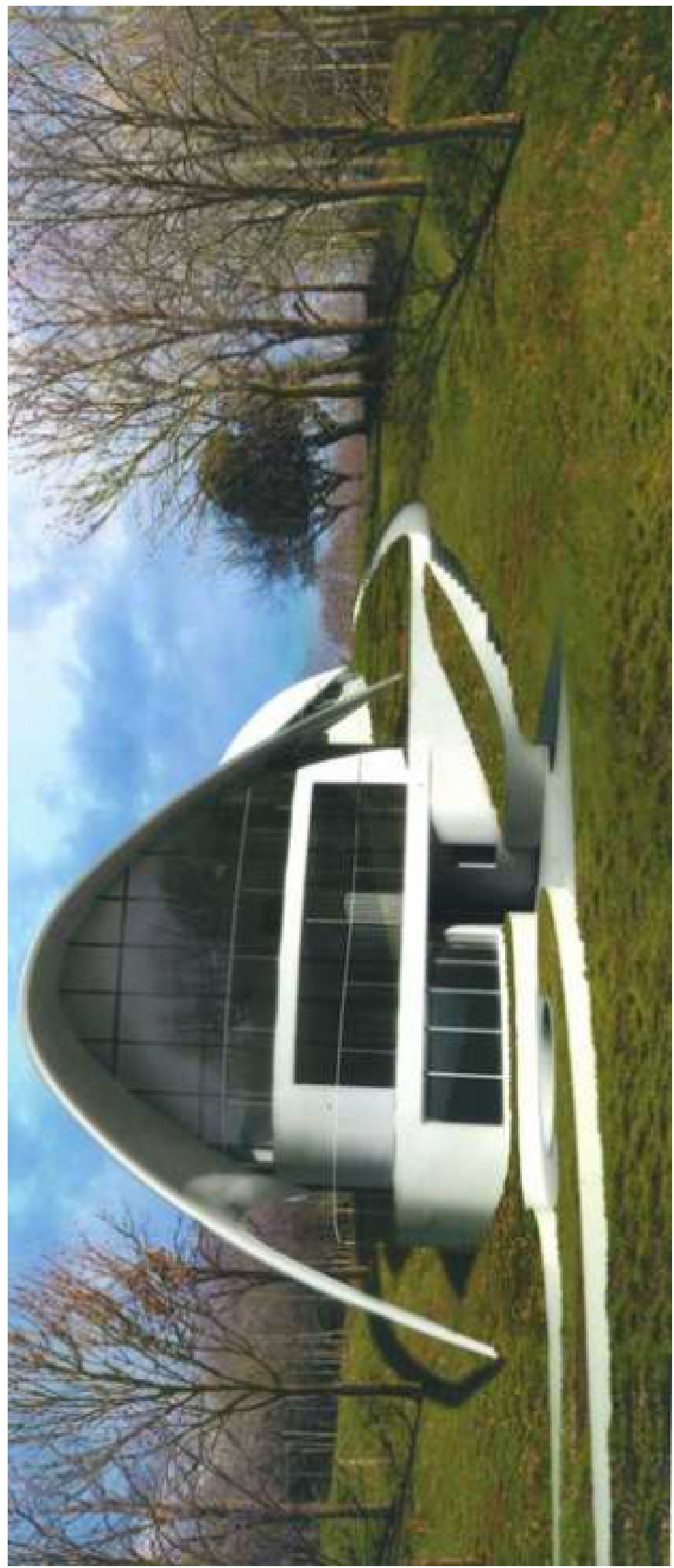




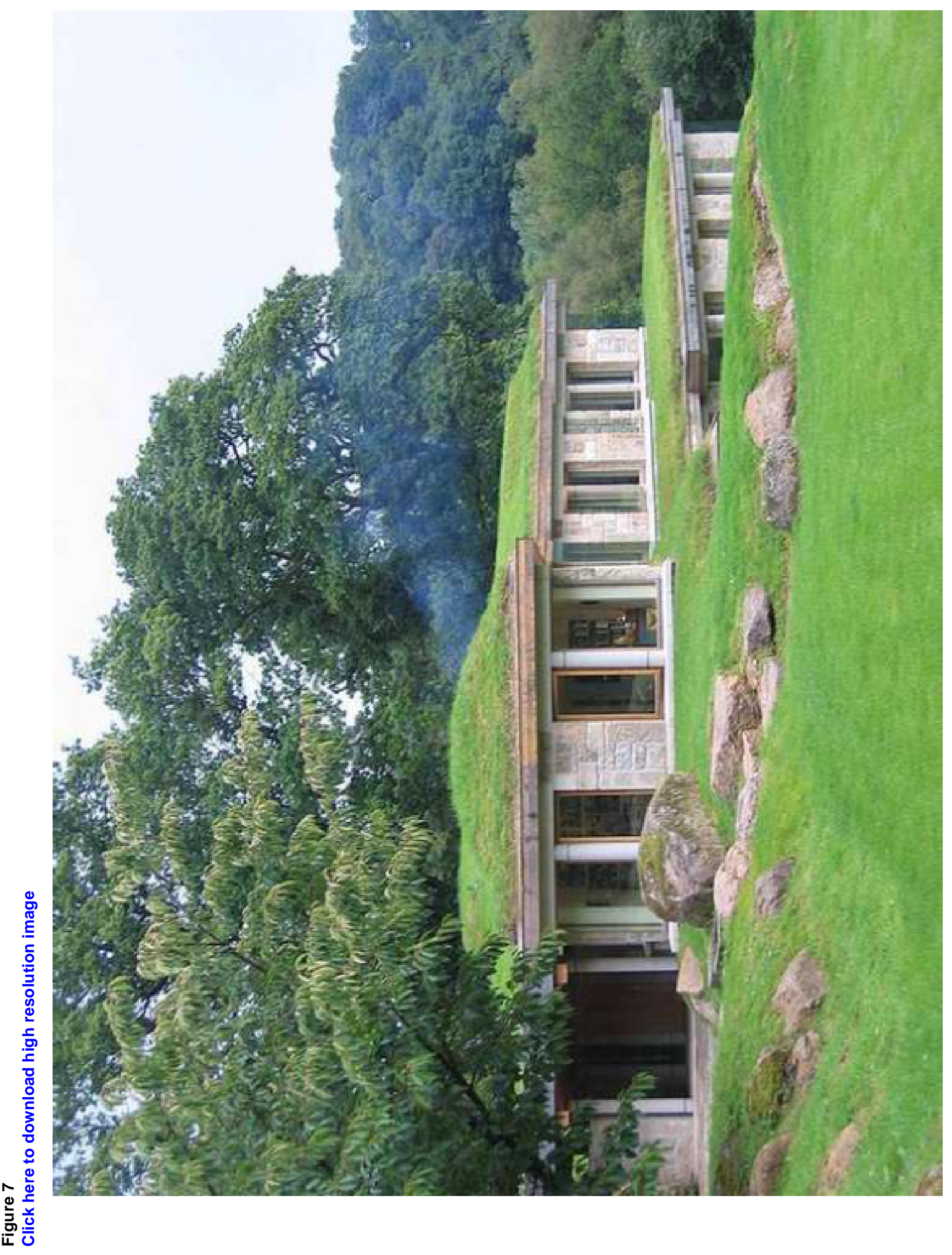




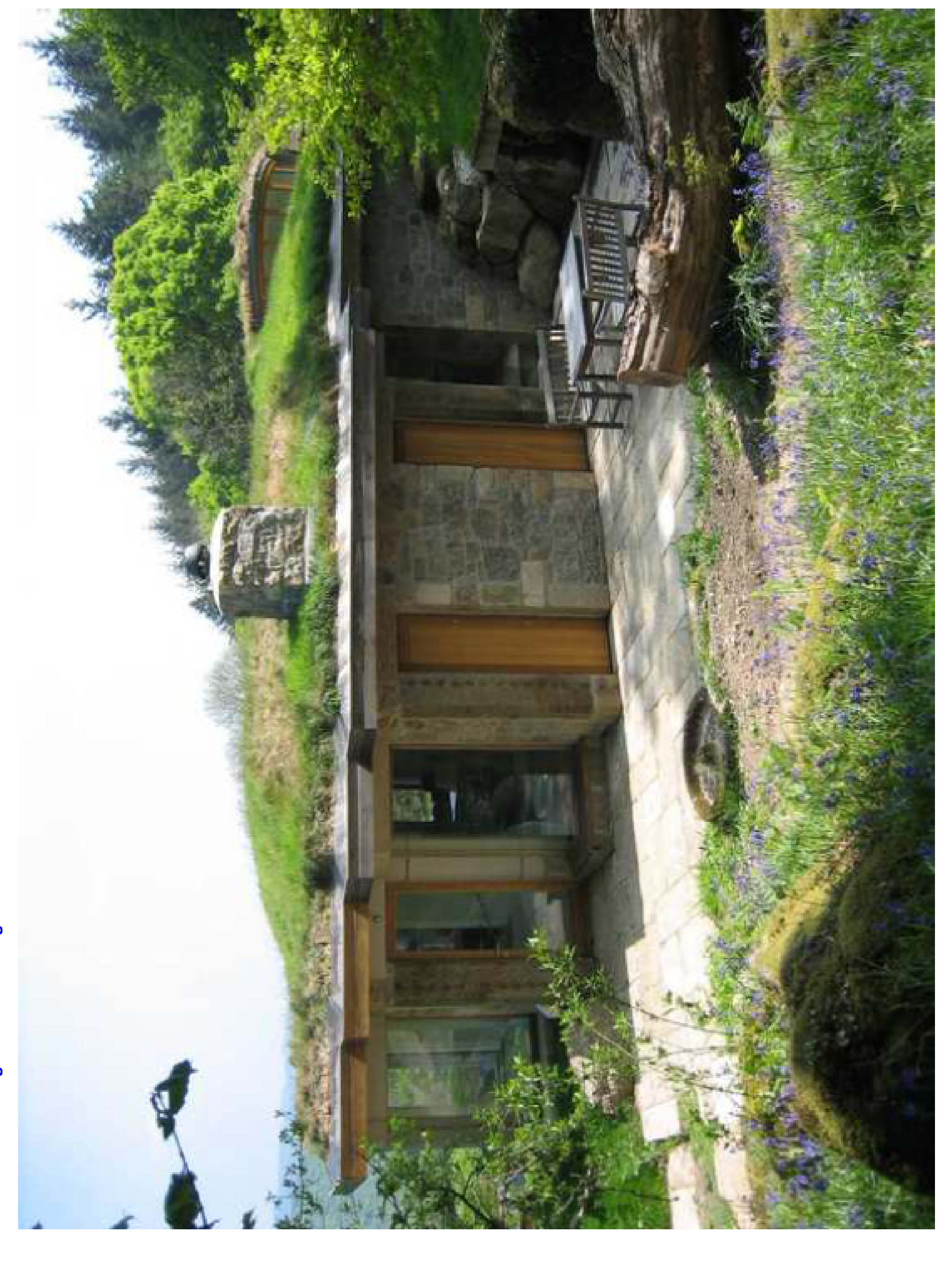




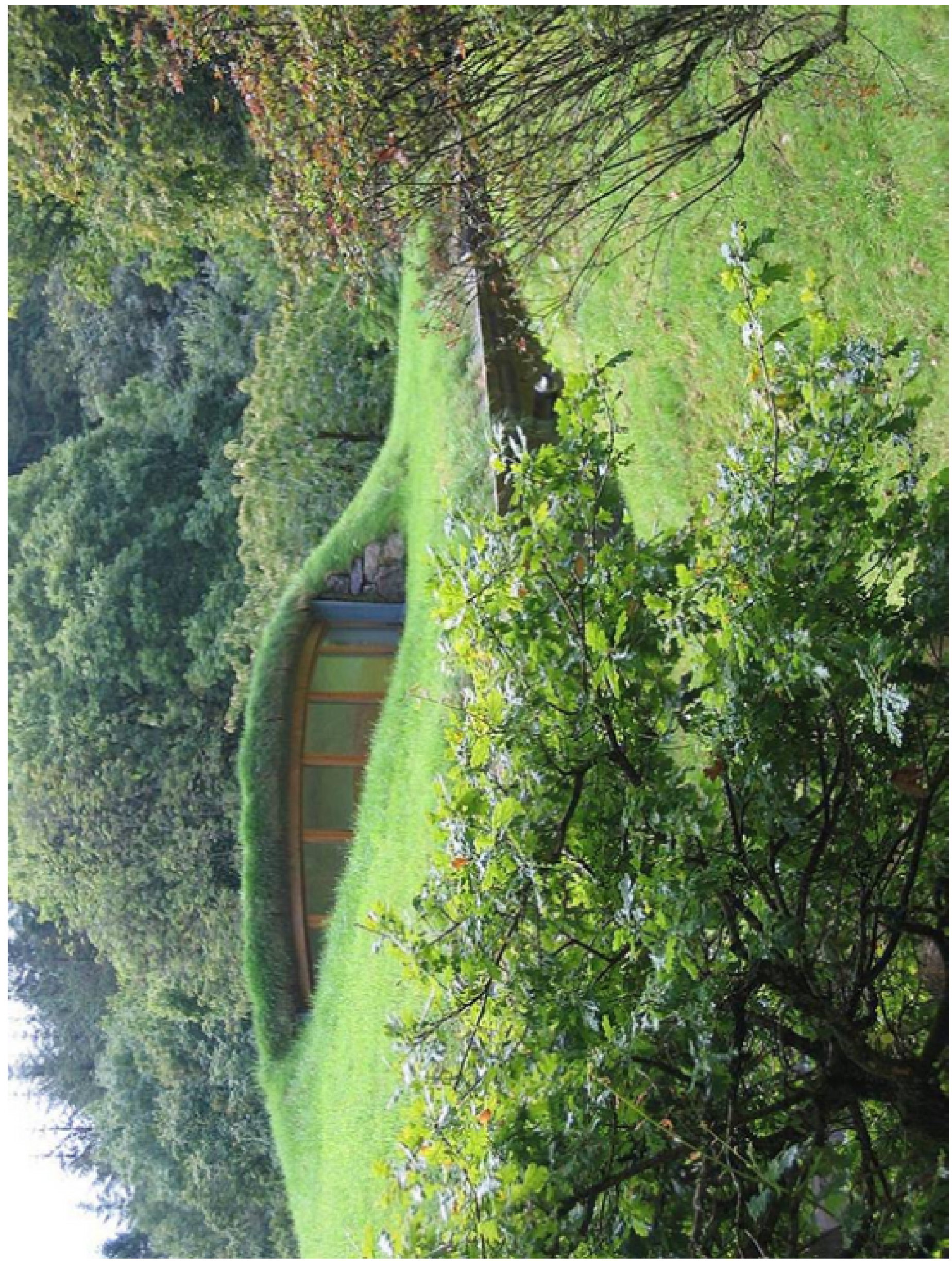




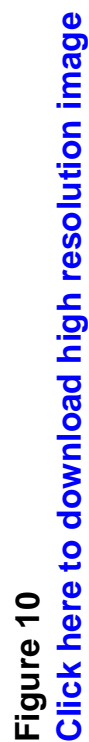

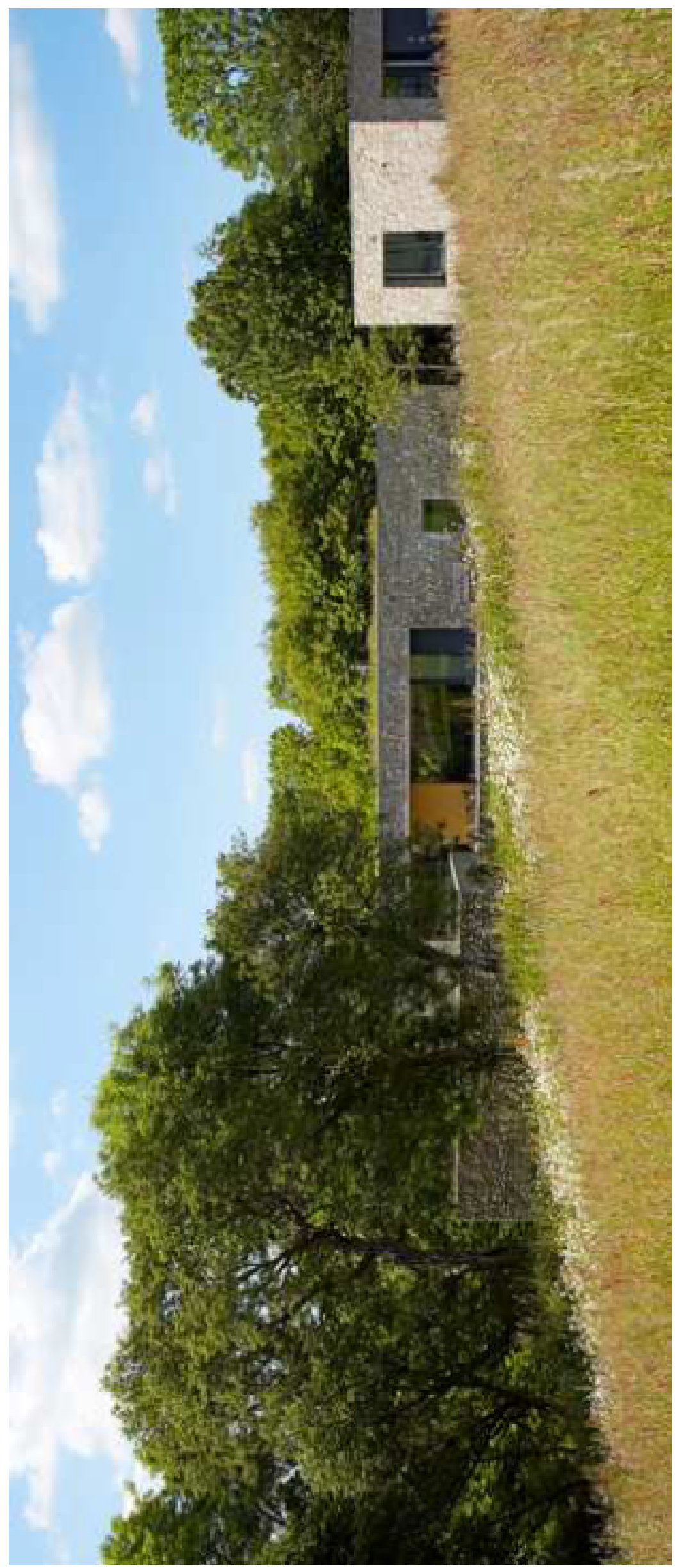




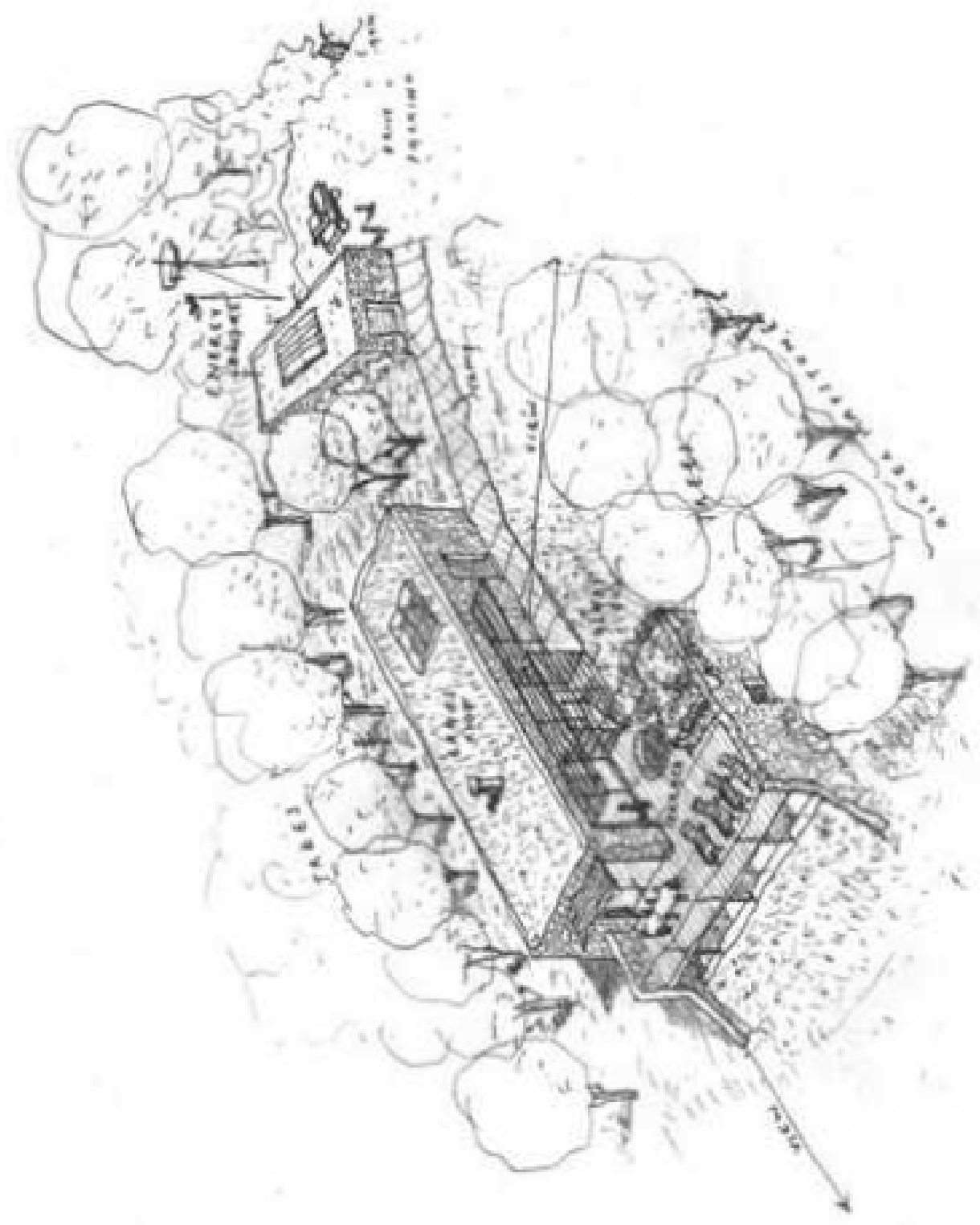

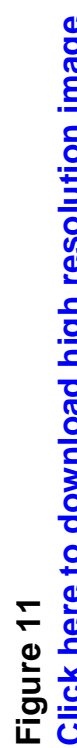




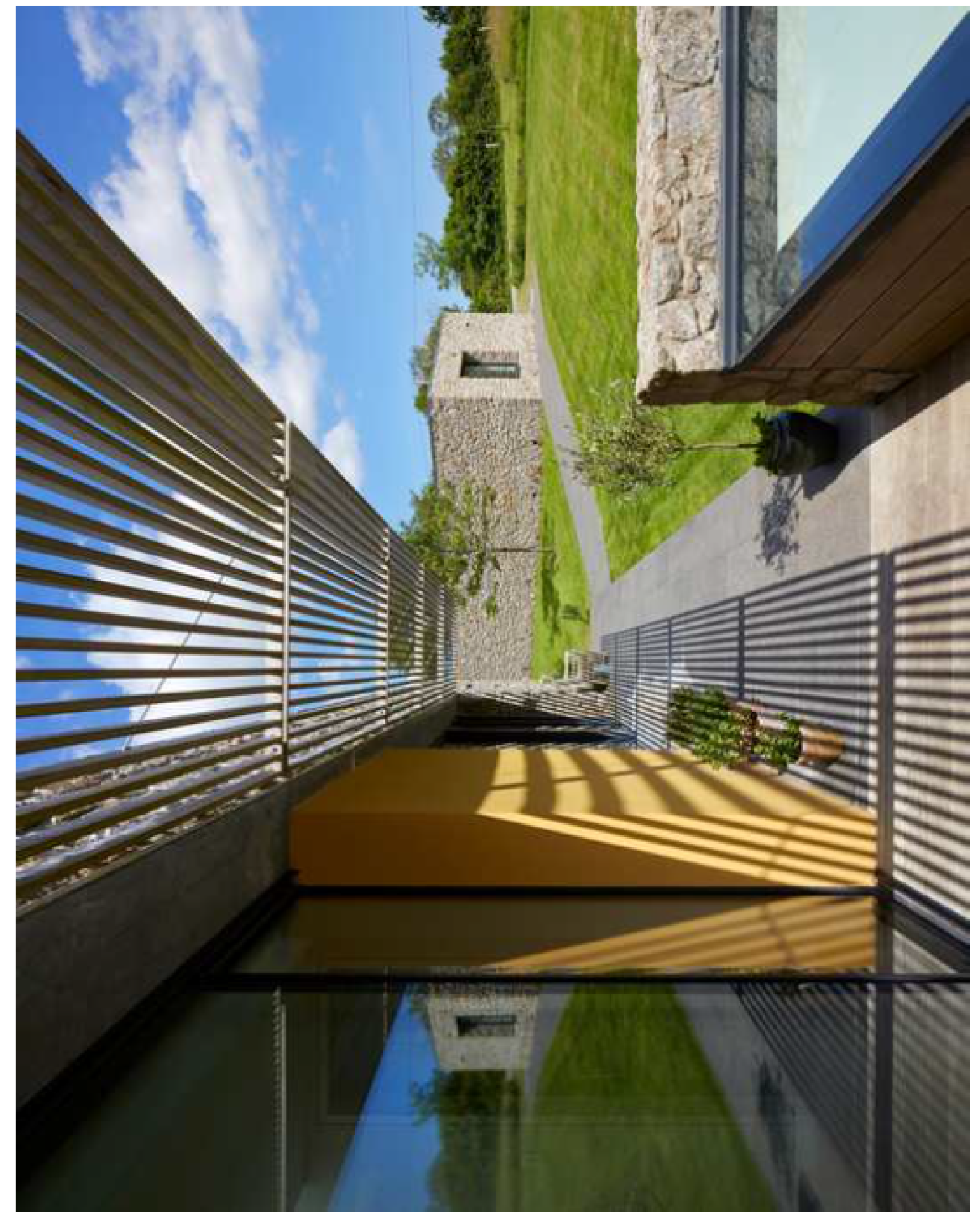

님

인

总

i4 


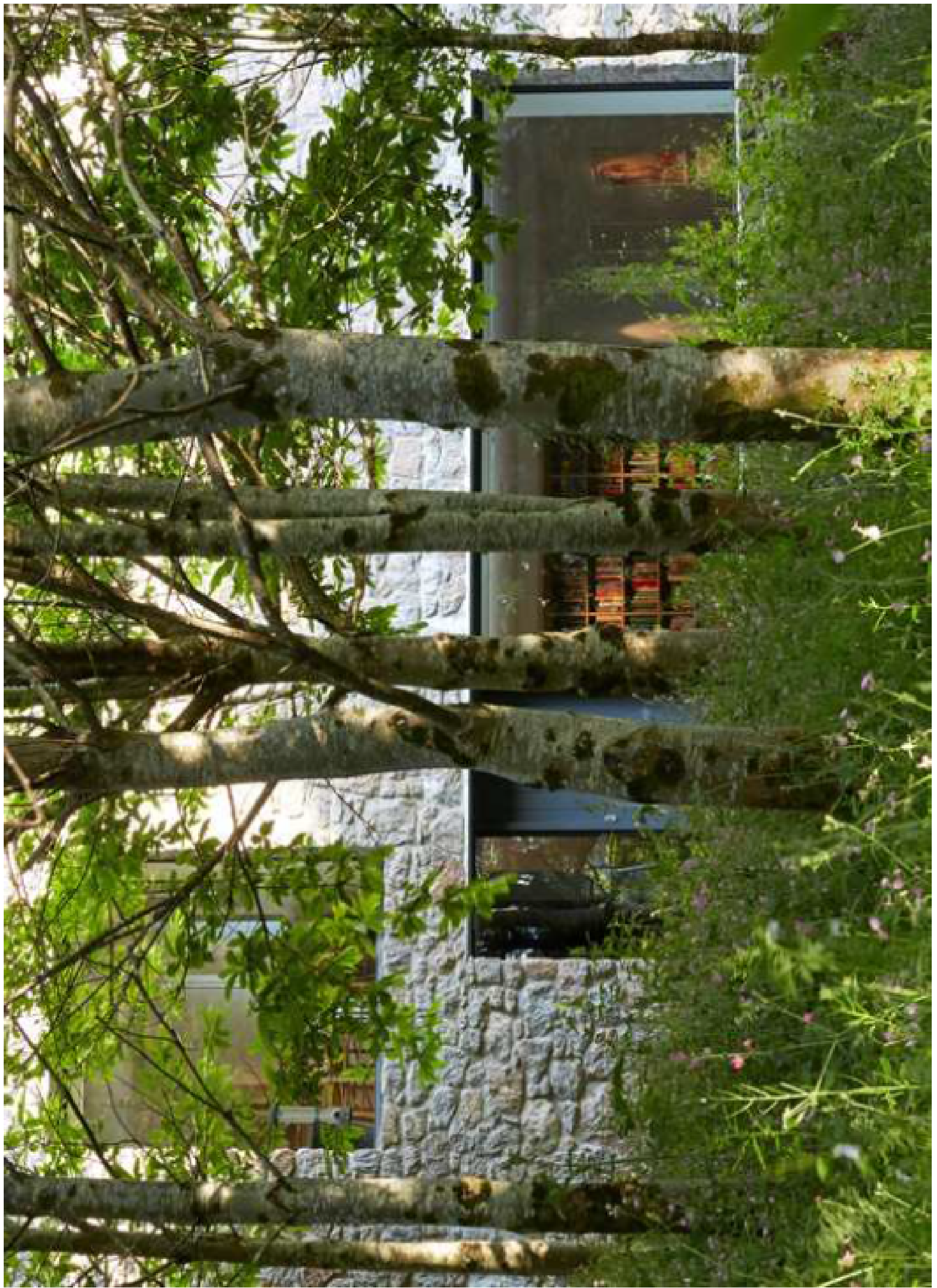

